30. A Revision of the Family Pantophthalmidas [Diptera], with Descriptions of New Species and a new Genus. By Major E. E. Austen, D.S.O., F.Z.S.

[Received May 29, 1923 : Read June 12, 1923.]

(Text-figures 1-11.)

Table of Contents.

(a) Inge

(a) Introduction and Acknowledgments .................. 551

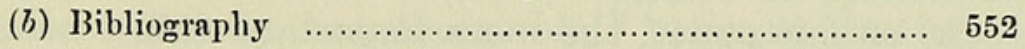

(c) Geographical Distribution ............................. 552

(d) Tnxonomic Position ................................... 553

(e) Bodily Dimensions in Pantophthalmida compared with those of Exceptionally Large Diptera belonging to other Families._Giantism................................. 554

(f) Life-history and Bionomics .............................. 556

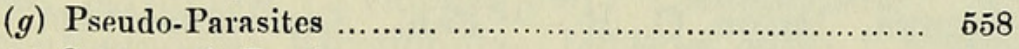

(h) Systematic Portion .................................. 559

(a) Introduction and Acknowledgments.

In spite of, as compared with the vast majority of Diptera, imposing size and striking coloration-characters likely to attract the attention of collectors in countries in which the flies forming the subject of this paper are found-Pantophthalmidæ (formerly known as Acanthomerida) are singularly rare in collections. It is clifficult to suggest even a possible reason for this, unless it is to be found in the habits of the adult insects, which probably spend most of their time in the depths of Neotropical forests.

At the present moment the series of these great Diptera in the British Museum (Natural History), though doubtless the most extensive in any collection in Europe, consists of only sixty specimens. These, however, include no fewer than twenty-four examples from the collection of the late M. J. M. F. Bigot, which Mr. J. E. Oollin, F.E.S., has most generously presented to the National Collection during the preparation of this paper. The fact that among M. Bigot's series of specimens are the types of five species, described by himself, Maequart or Bellardi, renders this addition peculiarly valuable, and its timely acquisition has enabled the writer in the course of subsequent pages to elucidate for the first time a considerable amount of synonymy. It is therefore a pleasant task hereby to express to Mr. Collin, on behalf of the Museum, sincere thanks for his public-spirited and most welcome gift.

Acknowledgments are also due to Professor E. B. Poulton, F.R.S., F.Z.S., for the kind loan of the Pantophthalmid material. 
amounting to twenty specimens, in the Hope Department of the Oxford University Museum; and to Dr. Hugh Scott, F.E.S., for similarly allowing the author to examine a female of Puntophthalmus chuni Enderl. and a larva (represented in text-fig. 1, on p. 557) of $P$. tabaninus Thunb., both of which are the property of the University Museum of Zoology, Cambrilge.

It only remains to add that, unless otherwise stated, all specimens mentioned in the following pages, including the types of new species, are in the British Museum (Natural History).

\section{(b) Bibliography.}

Apart from descriptions of genera and species already published, references to which will be found in the "Systematic Portion" (h) of this paper, the more important items comprised in the scanty literature of Pantophthalmida are the following :-

Brauer, Fr.-Description of a dried larva of Pantophthalmus (Acanthomera) frauenfeldi Schin. Denkschr. K. Alsad. Wiss., Math.-Naturw. Cl., Bd. xlvii. p. 25, Taf. ii. figs. 25 a-25 e (Wien, 1883).

Osten Sacken, Baron C. R.- "Fam. Acanthomeridæ." Biol. Centr.-Amer., Diptera, vol. i. pp. 63-68 (1886).

Fiebrig, K.- "Eine morphologisch und biologisch interessante Dipterenlarve aus Paraguay (Acanthomera teretruncum sp. n. Fiebrig)." Zeitschr. f. wiss. Insektenbiologie, Bd. ii. pp. 316-323, 344-347, figs. 1-19 (1906).

Williston, S. W.- "Family Acanthomeridæ." Manual of N. Amer. Diptera, 3rd Ed., pp. 173-175, figs. 2, 61, 62 (London: Wm. Wesley \& Son, 28 Essex Street, Strand, 1908).

Enderlein, G.-“"Die Dipteren-Familie Pantophthalmiclæ." Zool. Anzeiger, Bd. xli. pp. 97-118, figs. 1-15 (1912).

Enderlein, G.-.."Weitere Beiträge zur Kenntnis der PantophthaImiden." Zool. Anzeiger, Bd. xliv. no. 13, pp. 577586 (July 28, 1914).

Hermann, F.- "Ein neuer Pantophthalmus nebst kritischen Bemerkungen über die Systematik der Pantophthalmiden (Dipt.)." Deutsche Ent. Zeitschrift, Jahrg. 1916, pp. 4349, Abt. 1, 2 (1916).

\section{(c) Geographical Distribution.}

Pantophthalmidæ are confined to the Neotropical Region, where, however, their range is wide, extending from Mexico to Paraguay, and including at least a portion of the West Indies. It is true that, as pointed out by Osten Sacken (loc. cit. p. 66), Thunberg's statement ( $c f$. infra, p. 562) as to the provenance of the type of Pantophthalmus tabaninus - the first species of this family to he described-"still requires confirmation." Neverthe- 
less, considering that some eleven years ago the same species (subsequently regarded by Knab as new, and described by him under the name Pantophthalmus fastuosus) was found by Mr. F. W. Urich breeding in 'Trinidad; that, as is well known, the Dipterous fauna of the West Indies generally is "essentially a common one, with a strong South American facies"*; and that the islands of the Lesser Antilles are only separated one from another by short intervals of sea-there can be no real reason to doubt the accuracy of Thunberg's century-old assertion that the type of this species came from St. Barthélemy I.

\section{(d) Taxonomic Position.}

Williston('North American Diptera,' 3rd Ed., p. 175, 1908), who places the "Family Acanthomeridæ" between Stratiomyiidæ and Tabanidre, writes:- "The relationships of the family are very close indeed to the Stratiomyidx, and the families might, very properly, be united." Kertész, however, in vol. iii. of his 'Catalogus Dipterorum,' published in the same year, gives the families embraced by the volume in the following sequence: Stratiomyiidæ; Erinnidæ (Xylophagidæ); Cœnomyiidæ; Tabanidæ ; Pantophthalmidæ; Rhagionidæ (Leptidæ olim). Enderlein, on the other hand (Zool. Auz., Bd. xli. p. 97, 1912), considers that, from a phylogenetic standpoint, the Pantophthalmidæ are extraordinarily closely allied to the Xylophagidæ and Cœnomyiidæ, and that the morphological relations between all three are so pronounced that they might be regarded as groups belonging to a single family, namely the Xylophagidæ. The latter would then be divided into the subfamilies Xylophaginæ, Cœnomyiinæ, and Pantophthalminæ. Remarking that the presence or absence of spines on the scutellum, the relative size of the head and differences in bodily shape, whether slender or thickset, furnish insufficient grounds for the separation of families, Enderlein proceeds to show with the help of a diagram that in venation also the differences between Pantophthalmidær, Xylophagidæ, and Cœnomyiidæ are unimportant. Hermann, in his paper published four years later, while criticising Enderlein somewhat severely in connection with other details, nevertheless (Deutsche Ent. Zeitschr., Jahrg. 1916, p. 47, 1916) expresses his complete agreement with him (and disagreement with Kertész) in respect of the closeness of the relationship between the Pantophthalmidæ, regarded as a family, and the Xylophagidæ and Cœnomyiidæ.

There can be no doubt that the views of Enderlein and. Hermann as to the systematic position of the Pantophthalmidre nre correct, and indeed, in order to be sntisfierl upon this point, it is only necessary to compare two representative species, such as P'antophthalmus pictus Wied. and Xylophagus ruficeps Lw.

In view of the life-history of Pantophthalmidæ (vide infra (f)),

* Williston, Trans. Ent. Soc. Lond. 1896, p. 445 (1896). 
it is perhaps worth while to recall that the preliminary stages of Xylophagide and Cœnomyiidæ are also associated with trees, albeit in a dead or mouldering condition, the larvæ, which in the case of the two latter families are carnivorous and predaceous, living in decaying wood and under bark.

\section{(e) Bodily Dimensions in Pantophthalmidæ compared with those of Exceptionally Large Diptera belonging to other Families.-- Giantism.}

Although, as will be seen directly, in wing-expanse, and of course in length of leg, Pantophthalmidæe are surpassed by certain Tipulidæ of abnormal size, while length and wing-expanse in the largest species are about the same as or somewhat below the corresponding dimensions of the largest representatives of the Mydaidæ, the members of the present family as a whole are undoubtedly by far the bulkiest, and therefore the largest of all Diptera.

Among slenderly built Diptera, the largest forms are to be found in the Tipulidæ, wherein, as regards actual size, certain species of the genus Ctenacroscelis Enderlein are probably without existing rivals. Thus, a male belonging to a variety of Ctenacroscelis brobdignagius Westw., from China (N.-W. Sze Chuen), just over $39 \mathrm{~mm}$. ( $1 \frac{1}{2} \mathrm{inch}$ ) in length, has a wing-expanse of $104 \mathrm{~mm}$. (rather more than 4 inches), while the outstretched legs cover an area at least $6 \frac{3}{4}$ inches in length by 5 inches in breadth.

Although the family Mydaidæ includes a number of species, the representatives of which are of moderate dimensions, certain members of the genus Mydas, which are among the largest of Diptera, are relatively gigantic. By way of illustration, mention may be made of Mydas pragrandis Austen, a male of which from Brazil has a wing-expanse of $85 \mathrm{~mm}$. (between $3 \frac{1}{4}$ and $3 \frac{1}{2}$ inches), while the length of this insect, exclusive of the long and prominent antennæ, is $48 \mathrm{~mm}$. (between $1 \frac{3}{4}$ and 2 inches) *. The dimensions of this species, in fact, as represented at any rate by the type and paratype (both males) in the National Collection, are but slightly larger than those of the somewhat aberrant representative of the Pantophthalmidæ originally described by the

* Writing with reference to what is almost certainly the female of this species, of which he gives a life-size illustration derived from a photograph, Williston (N. A merican Diptera, pp. 16,17, fig. 1, 1908) furnishes considerably higher measurements, remarking:- "The largest specimen of a fly of which I have knowledge is that figured herewith natural size, pertaining to an indeterminable species of Mydas from South America. The length of this specimen from the tip of the antennæ to the extremity of the abdomen, is sixty-seven millimeters, or, omitting the antenna, fifty-two millimeters; the expanse of wings one hundred and seventeen millimeters, or a little more than four and one-half inches. The smallest dipteron that I have ever observed in the examination of many thousand specimens and five or six thousand species, is a cecidomyid measuring a trifle less than one-half millimeter, also omitting the antennæ. In other words, the Mydas is more than one million times the size of the cecidomyid. Possibly there are still greater discrepancies between the largest and smallest specimens of the order, but in all probability not much." 
author as Rhaphiorhynchus rothschildi, for which a new genus is erected in the present paper ( $c f$. p. 596).

Turning to the Asilidæ, we find in this enormous family a wide range in size, and a considerable number of species which, though smaller than the larger examples of the genus Mydas such as that just mentioned, are yet of exceptional dimensions, some of the largest forms being met with, for example, in the genera Proagonistes, Alcimus, Phellus, Blepharotes, Hyperechia, and Proctacanthus. A male belonging to an undescribed species of Proagonistes from Madagascar, $41 \mathrm{~mm}$. (between $1 \frac{1}{2}$ and $1 \frac{3}{4}$ inch) in length, has a wing-expanse of $80 \mathrm{~mm}$. (between 3 and $3 \frac{1}{4}$ inches); while, owing to the extraordinary length of the hind legrs, the space from the tips of these, when outstretched, to those of the similarly extended front legs measures at least $82.5 \mathrm{~mm}$. ( $3 \frac{1}{4}$ inches). The slender-bodied Alcimus brevipennis Ric., from! Natal, has in the female sex a length of $44 \mathrm{~mm}$. (just under $1 \frac{3}{4}$ inch), though its wing-expanse amounts only to $55 \mathrm{~mm}$. (between 2 and $2 \frac{1}{4}$ inches). Among the much more stoutly built representatives of the Australian genus Phellus, a female from South Queensland, belonging to a species as yet undescribed, measures $50 \mathrm{~mm}$. (just under 2 inches) in length inclusive of the ovipositor, and has a wing-expanse of $81 \mathrm{~mm}$. (a little under $3 \frac{1}{4}$ inches). The female of Blepharotes coriarius Wied., from the same region, may measure $42 \mathrm{~mm}$. (between $1 \frac{1}{2}$ and $1 \frac{3}{4}$ inch) in length, and have a wing-expanse of $76 \mathrm{~mm}$. (3 inches). Several of the species of Hyperechia are bulky-bodied flies of large size, one of the largest, being $H$. (Laphria) consimilis Wood (syn. Dasyllis usambarce Lichtwardt), of which the type (a female from Natal) is $33 \mathrm{~mm}$. (over $1 \frac{1}{4} \mathrm{inch}$ ) long, and has a wing-expanse of $62.5 \mathrm{~mm}$. (very nearly $2 \frac{1}{2}$ inches). Among narrow-bodied Asilidæ (subfamily Asilinæ), an exceptionally large species is Proctacanthus (Asilus) penultimus Walk., the type of which-a male from India. - is $40 \mathrm{~mm}$. (over $1 \frac{1}{2}$ inch) long, and has a wing-expanse of. $60 \mathrm{~mm}$. (between $2 \frac{1}{4}$ and $2 \frac{1}{2}$ inches).

Lastly, as regards Pantophthalmidæ other than the species already mentioned, the wing-expanse in the case of females belonging to the largest forms such as Pantophthalmus bellardii Bell. may amount to $84.5 \mathrm{~mm}$. (a little over $3 \frac{1}{4}$ inches), and the length over all (i.e. including the ovipositor but not the antennæ) to $5+\mathrm{mm}$. (over 2 inches); while the broad, flat abdomen may measure $22 \mathrm{~mm}$. (considerably more than $\frac{3}{4}$ inch) in width at its widest point. In the female sex of certain other species, notably Pantophthalmus tabaninus Thunb., dimensions are often little below those just given. Species of Pantophthalmidæ however exist, in which, so far as it is at present possible to judge from the limited amount of material available for examination, the same standard of bodily development is not attained; and on the other hand there are indications that, in some cases at any rate (as, e.g. in $P$. tabaninus), the average size of the males is considerably less than that of the females. 
The fact remains, however, that in the adult state dimensions in Pantophthalmidx as a whole are greatly in excess of the normal in Diptera, and this small group of large flies consequently forms an interesting case of the phenomenon known as giantism, concerning which Williston (op. cit. p. 17) writes as follows :"Giantism in any group of animal life is a specialization, and is, in general, an indication of approaching decadence; enduringly small races are never the descendants of giants, for decrease in size means lessened vitality and incipient extinction. No strong or dominant group of flies, like the Tachinidæ, Dolichopodidæ, Syrphidæ, or Bombyliidæ, has ever had in the past a larger average bodily size than is found among their living representatives. On the other hand, those families composed to-day chiefly of large forms are ones already past their prime. These conclusions seem established for the larger forms of life, and I believe that they are in the main also applicable to insects."

\section{(f) Life-history and Bionomics.}

Until the year 1906, knowledge under this heading was limiterl to a brief, illustrated description by Brauer of a dried larva of Pantophthalmus (Acanthomerca) frauenfeldi Schin. from Bogot: (cf. "Bibliography," p. 552); and Osten 'Sacken's statement (Biol. Centr.-Amer., Diptera, vol. i. p. 66), published three years later on the authority of Mr. G. C. Champion, that "Acanthomerce are found in forests, alighting on trunks of trees." In the year referred to, however, Karl Fiebrig, of San Bernardino, Paraguay, working under the disadvantages contingent upon isolation and lack of entomological literature, published a most interesting account ( $c f$. "Bibliography," p. 552), illustrated by a series of figures, of the external and internal anatomy of the larva of Pantophthalmus pictus Wied. (infra, p.575). From the larvi found by him, Fiebrig succeeded in breeding out a pair of imagines, which, owing to the disadvantageous conditions just mentioned, he regarded as belonging to a new species, and accordingly described under the name Acanthomera teretrumcum.

Thanks to Fiebrig's observations, which were actually made in 1905 , and were confirmed seven years afterwards by Mr. F. W. Urich, in Trinidad, in the case of another species (Pantophthalmus tabaninus Thunb.), we now know that larve of Pantophthalmidae have the extraorilinary habit-unique among Diptera, so far as the present writer is aware-of boring in the solid wood of living trees, in which they make "nearly horizontal " tunnels, and feed upon the exuding sap. Although Fiebrig does not mention the name of the tree in which he found his larvæ, he states that its wood is "among the toughest of Paraguayan timbers, hard as these in general are," and that the tunnels made by the maggots are "sharply gouged out."

In view of Fiebrig's detailed account, which should be consulted by the student, it is scarcely necessary here to do more than draw 
attention to the accompanying figure (text-fig. 1), which displays the chief features in the external morphology of a larva-prubably nearly adult-of another species of the genus Pantophthalmus. 'This larva, which is preserved in spirit, is $32.5 \mathrm{~mm}$. (just over $1 \frac{1}{4}$ inch) in length, while the average ventro-dorsal diameter of the body-segments is $9.75 \mathrm{~mm}$. It was taken, with at least five other larve of the same kind, in the Island of Trinidad, B.W.I., in borings in the trunk of an Erythrina, a leguminous tree, which attains a height of from 15 to 20 feet.

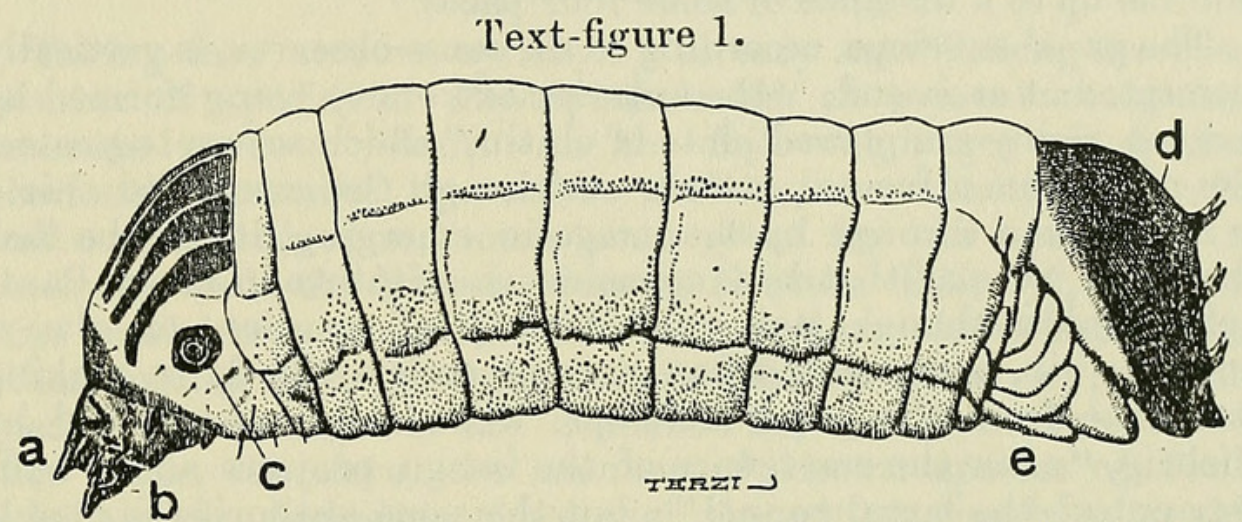

Larva of Pantophthalmus tabaninus Thumb. (lateral view), from boring in trunk of Erythrina tree (E. corallodendrum L. ?), Trinidad, B.W.I., March 1912 (F. W. Urich). $\times 2 \frac{1}{2}$. - From specimen kindly lent by Dr. Hugh Scott, University Museum of Zoology, Cambridge.

$a$, labrum ; $b$, left mandible; $c$, left anterior (prothoracic) spiracle or stigma ; $d$, dorsum of 8 th post-thoracic segment, which is very heavily chitinized; $e$, Fiebrig's "finger-shaped bodies"- in all probability an auxiliarv respiratory apparatus, employed when the posterior stigmata are unable to function, owing to the larval tunnel being full of sap.

The stout labrum and the extremely powerful mandibles together form a "drill," by means of which the larva is able to bore in solid wood; the equally heavily chitinized dorsum of the 8 th post-thoracic segment closes the tunnel from behind, and protects the larva from an attack in the rear. 'The posterior stigmata open on the posterior (ventral) surface of this segment, in a mouth-like chamber between it and the 9 th post-thoracic segment, which bears the "finger-shaped bodies." When the latter segment is in the position shown in the figure, the posterior stigmata are completely closed.

In the adult Pantophthalmid larva, the number, size, and arrangement of the backwardly directed spines on the 8 th post-thoracic segment perhaps afford characters of specific importance ( $c f$. Brauer, loc. cit. Taf. ii. tigs. $25 a, 25 b)$.

In the Trinidad larva, the longitudinal strips of chitin embedded in the integument of the prothoracic segment, to which the striped appearance of the latter is due, are reddish brown, while the powerfully developed labrum and mandibles, and the heavily chitinizerl dorsal surface of the 8 th post-thoracic segment are deep black; the prevailing tint of the remainder of the body is that of old ivory. There can be little doubt, however, that prolonged immersion in alcohol has had a bleaching effect, since Fiebrig describes the nine "soft" body-segments in the larva discovered by him as "bluish green," owing to the "intense blue tint" of the abundantly developed fat-body; it is also worthy of 
note that in life, according to the same author, the "finger-shaped bodies" (see text-fig. 1 and explanatory text) are bright green. The dorsal surface of the prothoracic segment, though far less heavily armoured than that of the 8th post-thoracic segment, nevertheless, strengthened as it is in the manner already referred to, is quite hard, and may well serve to protect the tunnelling larva against possible injury from sharp splinters of wood.

An interesting point with reference to the living larva of Pantophthalmus pictus is noted by Fiebrig, who writes that, "when in the tree-trunk it produces rasping sounds, distinctly audible up to a distance of some four paces."

The pupal envelope, according to the same observer, is vertically truncated at each end, "the anterior extremity being formed by . a stout, richly sculptured plate of chitin," which serves to protect the pupa from a frontal attack. Although this armoured shield is not broken through by the imago in emerging, it may be that the facial "beak," that is so conspicuous a feature in many Pantophthalmidæe though not exhibited by all species, or always developed in both sexes, when present assists the fly in making its escape from the pupal envelope. The latter, we are told by Fiebrig, "after the emergence of the imago, projects about halfway out of the larval tunmel"; but the same authority is unable to state whether the pupa makes its way to this point by its own efforts, or whether the pupal envelope is dragged along with it by the escaping fly.

"Metamorphosis," writes Fiebrig, "appears to be very protracted. A larva $35 \mathrm{~mm}$. in length, and apparently nearly fullgrown, was kept under observation from July 31, 1905, onwards. The imago emerged in the afternoon of January 11, 1906, a few weeks before which date it was found that the insect was still in the larval state; this would point to a pupal stage of very short duration."

Whether larvæ of Pantophthalmidæ are of economic importance, as destroyers of timber of commercial value, is an interesting point which awaits determination. So far as can be ascertained, the wood of Erythrina (E. corallodendrum L.?), in which the larvæ of Pantophthalmus tabaninus Thunb. were found by $\mathrm{Mr}$. F. W. Urich, in Trinidad, is of little or no utility. But the posisibility of commercial value is at any rate not excluded in the case of the unknown Paraguayan tree referred to by Fiebrig, as to which we are told that the wood is exceedingly hard and extremely rich in sap, "yielding an abundance of evil-smelling fluid on being injured."

\section{(g) Pseudo-Parcusites.}

Pseudo-parasites in the shape of Gamasid mites are of extraordinarily common occurrence on Pantophthalmidæ, and many instances of such infestation are recorded in the following pages. The mites, on being submitted by the author to his colleague Mr. A. S. Hirst, F.Z.S., for identification, were found by him in 
every instance except one to be conspecific, and to be nymphs of a species of Trachytes, which Mr. Hirst will describe in a forthcoming paper as new ( $c f$. p. 565). In the single case forming the exception, the pseudo-parasite was determined by Mr. Hirst as an adult female of Macrocheles, sp. incert. (vide p. 588). It would seem that these pseudo-parasites must infest the borings of the larva, and attach themselves to the flies as the latter emerge fiom the pupa-case.

\section{(h) Systematic Portion.}

Taking into account synonymy already established, the total number of species of Pantophthalmidæ at present recognized amounts to twenty-four. In the following pages ten species, previously described by various authors, are admitted as valid and commented upon, notes being given on the specimens of these species in the British Museum (Natural History), or otherwise available to the writer for examination; the names of nine other species, hitherto accepted, are sunk-as synonyms; and six species and one genus are described as new. As the result of this paper, therefore, the number of known species of Pantophthalmidæ, including those that the author has been unable to examine, will stand at twenty-one. It is explained below that, in agreement with Kertész, and contrary to the course adopted by Enderlein, the genus Pantophthalmus Thunb. is treated as including Acanthomera Wied. In view of the limited amount of material at the author's command, and since as yet both sexes are known in the case of only a minority of species, with much regret no attempt has been made to construct a synoptic table. Should the publication of the present paper fortunately result in a considerable expansion of the National Collection of these interesting Diptera, the construction of a reliable table of the kind in question may eventually be possible.

\section{Genus Pantophthalmus Thunberg.}

Pantophthalmus 'Thunberg, Götheborgs Kongl. Wettenskaps och Witterhets Samhällets Nya Handlingar, iii. Delen, p. viii (1819).

Acanthomera Wiedemann, Diptera Exotica, Pars i. p. 60(1821). Megalomyia Bigot, Ann. Soc. Ent. France, $5^{\mathrm{e}}$ Sér., T. x., Bull. p. v (1880).

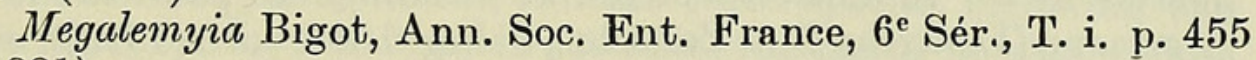
(1881).

After due consideration, it has seemed better to follow Kertész (Cat. Dipt. iii. p. 294 (1908)), who gives the synonymy printed above, rather than Enderlein (Zool. Anz., Bd.xli. p. 100 (1912)), by whom Pantophthalmus Thunb. and Acanthomera Wied. are treated as generically distinct. The course adopted by Kertész appears the more reasonable one under the circumstances, in spite 
of lack of complete agreement among the species mentioned or described in the following pages, in respect of certain structural details. Included among the latter are:-The degree of development of the facial "beak"; the shape of the terminal segment of the maxillary palpus; the shape of the terminal division of the third (compound) segment of the antenna in the female; and the presence or absence of a distinct subfemoral spine on the hind legs.

Although, by concentrating attention on one or other of these characters and disregarding the remainder, it would perhaps be possible in the case of certain species to select distinctions of apparently generic value, yet in other forms intergradations occur which make the drawing of a hard and fast line of demarcation impossible. Thus, to take only one of the characters referred to:-Enderlein (loc. cit. p. 99), writing of the terminal division (called by him the tenth segment) of the female antemna, says that this "in Pantophthalmus tapers gradually to a point, but in Acanthomera and Rhaphiorhynchus becomes but little narrower towards the end, and then, just before the tip, is suddenly pointed." This statement is certainly true if we compare the antenna of the female in species such as Pcotophthalmus tabarinus Thunb., or P. bellardii Bell. (both of which belong to Pantophthalmus, sensû stricto) with that of the female of $\Theta . \mathrm{g}$. l'antophthalmus (Acanthomera) chuni Enderl. But when we exarnine the antenna in the fernale of Pantophthalmus pictus (Accinthomera picta) Wied.-a species with a well-marked subfemoral spine, and the genotype of Acanthomera-we find that it is intermediate between the two conditions. Moreover, in the female of Pantophthalmus vittatus (Acanthomera vittata) Wied.a species assigned by Enderlein himself (loc. cit. p. 107) to Pantophthalmus - the terminal division of the antenna is precisely of the type regarded by Enderlein as characteristic of Acanthomera.

As regards the maxillary palpus, the terminal segment of this structure is also subject to a certain amount of variation in shape in different species. Although usually slender and cylirulrical, and, at least in the female sex, longer than the remainder of the palpus, it is sometimes shorter and also stouter, albeit never swollen in the manner characteristic of the terminal segment of the palpus in Rhaphiorhynchus.

That Enderlein is in error when he asserts (loc. cit. p. 100) that in Pantophthalmus, sensû stricto, the facial beak is represented merely by a "rounded tubercle-like swelling" is pointed out by Hermann (Deutsche Ent. Zeitschr., Jahrg. 1916, p. 48 (1916)), who shows that in $P$. alienus Herm. the absence of a subfemoral spine on the hind legs is correlated with the presence of a "long, pointed, tooth-like facial process." A further example of the condition seen in $P$. alienus Herm, is afforded by the new species described below as $P$. batesi ( $f f$. p. 566), in the male of which, at any rate, while the facial beak, though small, is conspicuous and sharp-pointed, the posterior femora are either without a spine 
on the under surface, or display the merest vestige of such a structure.

'The truth is that characters such as those mentioned abore, however valuable for the distinction of species, are of less than generic importance, and, were it necessary, many arguments in support of this contention might be furnished from the accepted taxonomy in other families of Diptera.

Among characters of specific importance in the genus Pantophthalmus, may be mentioned wing-markings and, although this does not apply to the males of certain species which have the thorax unicolorous or nearly so, the markings on the dorsum of the thorax.

Wing-markings, in spite of their general similarity (with certain exceptions) throughout the family Pantophthalmidæ, will be found, if close attention be paid to details, to afford useful assistance not only in the distinction of species, but in the correct association of the sexes of the same species-a matter in some cases probably of far greater difficulty. Osten Sacken, in the course of a valuable disquisition on structural peculiarities and characters of specific importance in Pantophthalmidæe "Acanthomeridæ," Biol. Centr.-Amer., Diptera, i. pp. 65-66 (1886)), does not refer to wing-markings, but writes as follows with regard to markings on the thorax :- "The arrangernent of the stripes and spots on the thorax, an apparent monotony notwithstanding, offers excellent characters for the recognition of the species, and especially for the assorting together of male and female specimens of the same species." As regards the value of thoracic markings for the association of the sexes of a given species, the statement just quoted is only partially true. It certainly hold goods in the case of l'antophthalmus tabaninus Thunb. (the synonymy given on p. 562 below is based on and supported by the characteristic thoracic markings exhibited by this species), and $P$. vittatus (Acanthomera vittata) Wied. (as also in that of Rhaphiorhynchus planiventris Wied.); but it is entirely inapplicable to a species such as Pantophthalmus pictus (Acanthomera picta) Wied., in which the dorsum of the thorax is conspicuously striped in the female, but almost uniformly silvery, or a.t any rate without corresponding stripes, in the male. While the presence of sharply-defined, dark longitudinal stripes on the dorsum of the thorax (scutum) is charncteristic of the female sex in Pantophthalmus (and also in Rhaphiorhynchus), there are, in arldition to $P$. pictus Wied., at least three species, including one described for the first time in the following pages, in which, while the female is as yet unknown, the thorax in the male is without such stripes. In these species the dorsum of the male abdomen, be it, noted, has a silvery sheen. It is to be hoped that males and females of the species in question may ere long be caught in coit $\hat{\imath}$, or bred from larvæ or pupæ taken in the same tree-trunk, otherwise the correct association of the sexes in these cases may remain a matter of doubt for an indefinite period. 
In addition to sexual dimorphism of the kind just referred to, difficulties of determination in this genus are increased by the fact that in the case of certain species (at any rate $P$. tabaninus Thunb. and $P$. pictus $\mathrm{W}$ ied. - see below) the female abdomen, at least in dried specimens, sometimes shows colour-dimorphism as well. Failure to realize the occurrence of this phenomenon led Enderlein into error in constructing his synoptic tables (Zool. Anz. xli. pp. 101, 107 (1912)) - a fact which has already been pointed out by Hermann (Deutsche Ent. Zeitschr., Jahrg. 1916, p. $48(1916))$.

The number of species of Pantophthalmus recognized as valid in Kertész's 'Catalogus' (vol. iii. 1908) is fourteen. This total does not include Acanthomerc teretruncum Fiebrig (= Pantophthalmus pictus (Acanthomera picta) Wied.), since the description of the latter (1906) appeared between the compilation and publication of the volume of the late Dr. Kertész's monumental work in which the Pantophthalmidæe are included. Between 1908 and the present time, descriptions of nine species of Pantophthalmus supposed to be new have been published, including seven by Enderlein and one ench by Hermann and Knab; while Enderlein has rightly sunk Fiebrig's designation Acanthomera teretruncum as a synonym, besides disposing of $P$. helleri Enderl. in a similar manner. Thus for the moment the number of species of Pantophthalmus assumed to be valid stands at twenty-two. In the following pages, however, the names of no fewer than nine of these are shown to be synonyms, while six species are described as new; so that, as the result of the present paper, the genus Pantophthalmus is to be regarded as consisting of nineteen recognized species.

The genotype is Pantophthalmus tabaninus Thunb.

\section{Pantophthalmus tabaninus Thunb.}

Pantophthalmus tabaninus Thunberg, loc. cit. p. vii (1819). Acanthomera seticornis Wiedemann, Auss. zweifl. Ins. i. p. 108, Taf. ii. figs. l $a-1 c$ (1828). [New synonym.]

Acanthomera heydenii Wiedemann, op. cit. p. 555 (1828). [New synonym.]

Acanthomera immanis Wiedemann, op. cit. ii. p. 623 (1830). [New synonym.] Acanthomera rubriventris Bigot, Ann. Soc. Ent. France, $5^{\mathrm{e}}$ Sér., T. x., Bull. p. v (1880). [New synonym.]

Pantophthalmus fastuosus Knab, Insec. Inscit. Mens. vol. ii. no. 2, p. 27 (February 1914). [New synonym.]

According to Thunberg (loc. cit.), the type of $P$. tabaninus was obtained in St. Barthélemy I., in the West Indies.

Among the synonyms recorded above, the name Acanthomera seticornis (like Pantophthalmus tabaninus itself) was originally applied to the $\delta$ insect, while the designations Acanthomera heydenii, A. immanis, and A. rubriventris were bestowed upon 
the + . A study of the thoracic markings, which are characteristic of this species and present a striking agreement in both sexes, leaves no doubt as to the correctness of the synonymy here given. In spite of the fact that P'antophthalmus gigas Enderlein (Zool. Anzeiger, Bd. xli. p. 110, fig. 7 (1912)), described from the $q$ sex, is stated by its author (loc. cit.) to be devoid of pale spots on the lateral margins of the second and third abdominal tergites, it would seem not unlikely that this supposed species is also identical with $P$. tabaninus 'Thunb.

'The representatives of Pantophthalmus tabaninus Thunb. at present contained in the British Museum (Natural History) are as follows:--One $\sigma^{*},(?)$ Trinidad, B.W.I. (Gr. Robertson-ex coll. W. W. Saunders); one $q$, Venezuela, before 1847 (purchased from - Dyson); one $q$, Brazil, before 1849 (Mrs. Noel); one $\delta$, locality unknown (e.x coll. Alexander Fry); one ơ, Trinidad, B.W.I., before 1878 (Mrs. Cutter) ; one ơ, Macapá, R. Amazons, Brazil, 25. ii. 1896 (E. E. Austen), "on board Messrs. Siemens Bros.' Cable S.S. Faraday" ; one $q$, Nicaragua (E. A. Burns); one $q$, Colonia Hansa, Santa Catharina, Brazil (purchased from H. Rolle). Presented by Mr. J. E. Collin, F.E.S., from the Bigot collection, we also have the four specimens (including the type) of Acanthomera rubriventris Big., which are all $q$ ㅇ from Guatemala; and two $\delta$ of $P$.tabanimus, likewise from Guatemala, which, in Bigot's series, were placed with a $\delta$ of $P$. versicolor Austen (see below), above the label "Acanthomera seticornis, Wied. $o$," in Macquart's handwriting.

'The Hope Department of the University Museum, Oxford, possesses two $\delta^{\circ} \delta^{*}$ and two $ᄋ+q$ of $P$.tabaninus; of the former, one specimen is labelled "seticornis Wied.," but is without any indication as to provenance, while on the label of the other is written "Pará. Higgins, 1868 "; there is nothing to show the origin of the two +9 , which are labelled " $R$. planiventris."

The Liverpool School of Tropical Medicine has a $q$ of $P$. tabaninus from Pará, Dec. 1922 (Dr. Clarke).

In this species, in which the female usually, although not invariably, much exceeds the male in size, the ground-colour of the dorsum of the abdomen ranges from cinnamon-rufous * or vinaceous-rufous to blackish-brown or black. The dark thoracic stripes are the same in all cases, and, at least in the specimens available to the writer for examination, the silvery-white triangular spot near each posterior angle of the second and third abdominal tergites is always visible, although in some individuals less conspicuous than in others. In the case of the type of $P$. tabaninus, which, from the details furnished by Thunberg, is evidently a male, the dorsum of the abdomen, according to the original description, is "brown"; Wiedemann (loc. cit.) describes the dorsum of the abdomen in Acanthomera seticornis as "vivid

* For nnmes and illustrations of colours used for descriptive purposes in the presont pnper, see Ridgwny, 'Color Stnudards and Color Nomenclature' (Wnshington, D.C. Published by the Author, 1912).

Proc. Zool. Soc.-1923, No. XXXVII. 
ferruginous-yellow" (sehr brennend rostgelb), and the same region in A. immanis as "ferruginous." In the type of A. rubriventris Big. the ground-colour of the first four abdominal tergites is between ferruginous and vinaceous-rufous, while the hind borders of the second and third tergites, and the hind border of the fourth tergite except its lateral extremities, are black. Of the three paratypes of $A$. rubriventris, one agrees with the type in the coloration of its abdomen, while in the case of the other two the dorsum of the abdomen is reddish-brown. In the series of specimens of $P$. tabaninus in the National Collection, other than those just mentioned under Bigot's designation Acanthomera rubriventris, the six males have the dorsum of the abdomen (except its basal angles and the lateral borders of the first three tergites, which are black in this sex) cinnamon-rufous, vinaceousrufous, or ferruginous, while the venter is seal-brown. Of the four females comprised in the same series, one has the dorsum of the abdomen (except the lateral margins, which are black) dull amber-brown, while in the case of the other three individuals the corresponding region is for the most part blackish-brown; the venter in each specimen is dark seal-brown. Among the four. examples of $P$. tabaninus in the possession of the Hope Department, University Museum, Oxford, the two males have the dorsum of the abdomen cinnamon-rufous, apart from the black lateral borders of the first three tergites, and the basal angles of the fourth tergite, which are brown or blackish-brown. In one of the two females in the Oxford collection, the dorsum of the abdomen, with the exception of the small silvery-white spot near each posterior angle of the second and third tergites, is uniformly velvety-black. The corresponding region in the other specimen is brownish black, with an ochraceous-tawny tiansverse area in the centre of the hind border of the first segment, extending on to the front margin of the second; on the latter segment there is also a deep, brownish-tawny, transverse band, which is not very sharply defined, and does not reach the lateral extremities of the tergite; on both the second and third tergites, in front of the hind margin, there is a black transverse band.

It is interesting to note that, in the case of one of the females of $P$. tabaninus in the National Collection (the specimen referred to above as having been taken in Brazil prior to 1849 , by Mrs. Noel), the abdomen shows a very heavy infestation by nymphs of a Gamasid mite. The pseudo-parasites, which, in the dried condition at any rate, are light ochraceous-buff in colour, and measure about $0.4 \mathrm{~mm}$. in length, are present to the number of many hundreds on the dorsal surface of the abdomen, where they are packed so closely as to form large patches, while quantities are to be seen crowded together beneath and partially concealed by the hind margins of the tergites. Further specimens of the mite, although in small numbers as compared with those on the dorsum, are also visible on the venter. The male $P$. tabaninus taken by the writer at Macapa, R. Amazons, 25.ii. 1896, on 
board the Cable S.S. Faraday, shows a considerable number of what is evidently the same pseudo-parasite on the dorsal surface of its abdomen, while many instances of similar infestation in the case of specimens of other species of Pantophthalmidæ are noted below. Since therefore, even among the limited series of these flies available to the author for examination, representatives of various species are infested in this manner, it would seem that for some reason members of this family are peculiarly subject to to invasion by this Acarid. The author's colleague, Mr. A. S. Hirst, F.Z.S., to whom the mites have been submitted, has kindly supplied the following note:- "The pseudo-parasites are nymphs of a species of Trachytes, a Gamasid mite, and presumably are predatory forms, possibly feeding upon small mites or insects inhabiting the tunnel of the fly-larva. This habit of attaching itself to an insect host is no doubt of benefit to the mite, by widening its area of distribution."

\section{Pantophthalmus frauenfeldi Schin.}

Acanthomera frauenfeldi Schiner, Reise der österieichischen Fregatte 'Novara' um die Erde, Zool. Theil, Bd. ii. Diptera, p. 78 (1866).

Of this species, the National Collection possesses a 우 from Bogota, Colombia (ex coll. - Stevens, 1856), in which country the type was obtained; and a second $q$, from Peru ( $\epsilon x$ coll. J. M. F. Bigot; presented by J. E. Collin). The latter specimen, with thie type of Acanthomera crassipalpis Macq. (=Rhaphiorliynchus planiventris Wied.), and two other $q$ of of Rhaphiorliynchus planiventris Wied., stood in the Bigot collection above the label "Accuthomerc crcassipalpis, Macq., n. sp. ㅇ," in Macquart's handwriting.

Including the facial beak and ovipositor, the original Museum specimen measures just over $31 \mathrm{~mm}$. in length, instead of $35 \mathrm{~mm}$., which is the length of the type (also a $f$ ) as given by Schiner. The total length of Bigot's example, measured in the same way, is $32 \mathrm{~mm}$.

In the Hope Department, University Museum, Oxford, there is a solitary + of $P$. frauenfeldi from Macas, Ecuador (purchased from Stevens, 1862). The dimensions of this specimen, which is very much larger than the examples in the National Collection, are as follows:-Total length, including facial beak and ovipositor, $42.25 \mathrm{~mm}$. ; greatest width of abdomen (across hind margin of second tergite) $16.25 \mathrm{~mm}$.; wing-expanse $74.6 \mathrm{~mm}$. The terminal segment of the palpi in the Oxford specimen is slender, straight, and cylindrical, whereas the corresponding segment in the British Museum of from Bogota is curved outwards at the tip and distinctly swollen towards the base; in the of from the Bigot collection the palpi are damaged.

Two nymphs of the usual species of Gamasid mite (cf. remarks under 1 '. tabaninus above) are visible on the dorsum of the abdomen of the $q$ from Bogota. 


\section{Pantophthalmus batesi, sp. n. (Text-fig. 2.)}

o.-Length (one specimen) $24 \mathrm{~mm}$.; width of head $6.4 \mathrm{~mm}$.; greatest width of abdomen (across hind border of second tergite) $8 \mathrm{~mm}$.; length of wing $18.5 \mathrm{~mm}$.

Relatively small and (in ot sex at least) somewhat narrow-bodied species, with, in ot, a small but conspicuors, sharp-pointed facial "beak," unstriped thorax, and ochraceous-orange abdomen, which along each lateral margin bears a series of sooty-black spots or elongate blotches, and dorsal surface of which, except anterior. borders of second to fifth segments inclusive, has from certain angles the appearance of burnished silver; wing-markings presenting a general resemblance to those of $\mathrm{P}$. tabaninus T'hunb., but with conspicuous differences, notably a curved pale marl connecting for $/ \mathrm{s}$ of third longitudinal vein with costa; posterior femorca without, or with merest vestije of, a spine on under surfuce.

Head in of sex more flattened in an intero-posterior direction than that of $l$. tabaninus 'Thunb., and consequently less hemispherical in ontline when viewed from above; face, except beak, dusky drab; jowls and basi-occipital region clove-brown, clothed with similarly coloured hair; occiput olive-buff; facial beak blackish brown at base, distal attenuate portion chestnut-brown ; palpi light sepia-coloured, darker towards distal extremities; second segment * clothed beneath, towards distal extremity, with blackish-brown hair, terminal segment curved, slender, tapering to the tip ; first and second segments of antenna russet-coloureel, first segment thinly clothed with brownish hair, second segment, with some glistening orange-buff hair on distal margin (third segment missing in case of type). Thorax: ground-colour of dorsum cinnamon-drab, thinly suffused above with smolse-grey pollen, while lateral borders of dorsum are olive-buff pollinose; main portion of dorsum (scutum) markerl with five dull-black spots, of which two, smaller than remninder and nearly circular, are situated on line of transverse suture, one on each side of middle line; remaining spots transversely elongate and situated on hind border, one in middle line, the other two occupying the postalar calli, except inner extremities of latter' scutellum dullblack or blackish-brown, anterior angles and lateral border's smoke-grey pollinose; pleure and pectus blackish-brown and

* Note on tho number of segments in the maxillary palpus in Pantophthalmida.Fiebrig (Zeitschr. f. wiss. Insoktenbiol., Bd. ii. p. 346, 1906), in describing the species named by him Acanthomera teretruncum (=Pantophthalmus pictus (Acanthomera picta) Wied.), speaks of "the relatively long, three-jointed palpi." Williston (North American Diptera, 3rd Ed., p. 173, 1908), in a short genernl account of the "Family Acanthomerida," states that the palpi are "two-jointed." Lastly Euderlein (Zool. An\%., 13d. xli. p. 99, 1912) says that in Pantophthalmida, owing to the irregular transverse wrinkling of the palpus basad of the terminal segment, it is impossible to determine whether this portion is further segmented or not. There can be no doubt, however, that the maxillary palpus in this family consists of three segments, in which, while the second is often marked by conspicuous annuli or transverse wrinkles, the first owing to its short ness may easily be overlooked, although in many species distinguishable by darker coloration and a different arrangement of the hair. 
clothed with fine similarly coloured hair, dorsum, and lateral extremities of pronotum, clothed wtih ochraceous-buff hair. Abdomen: first tergite with each lateral extremity broadly black, though just in front of hind margin of segment black area shows a deep indentation of ground-colour above and below; second and third tergites with a scutiform or elongate black spot occupying each anterior angle, extreme hind margins of posterior angles of second tergite also black; fourth tergite with anterior two-thirds of lateral extremities sooty black; lateral extremities of fifth tergite blackish-brown ; sixth tergite entirely ochraceousorange; a straight transverse band running right across fore borcler of fifth tergite devoid of silvery sheen; on each of the three preceding tergites corresponding non-silvered band tapers towards lateral extremities of the tergite, which it fails to reach,

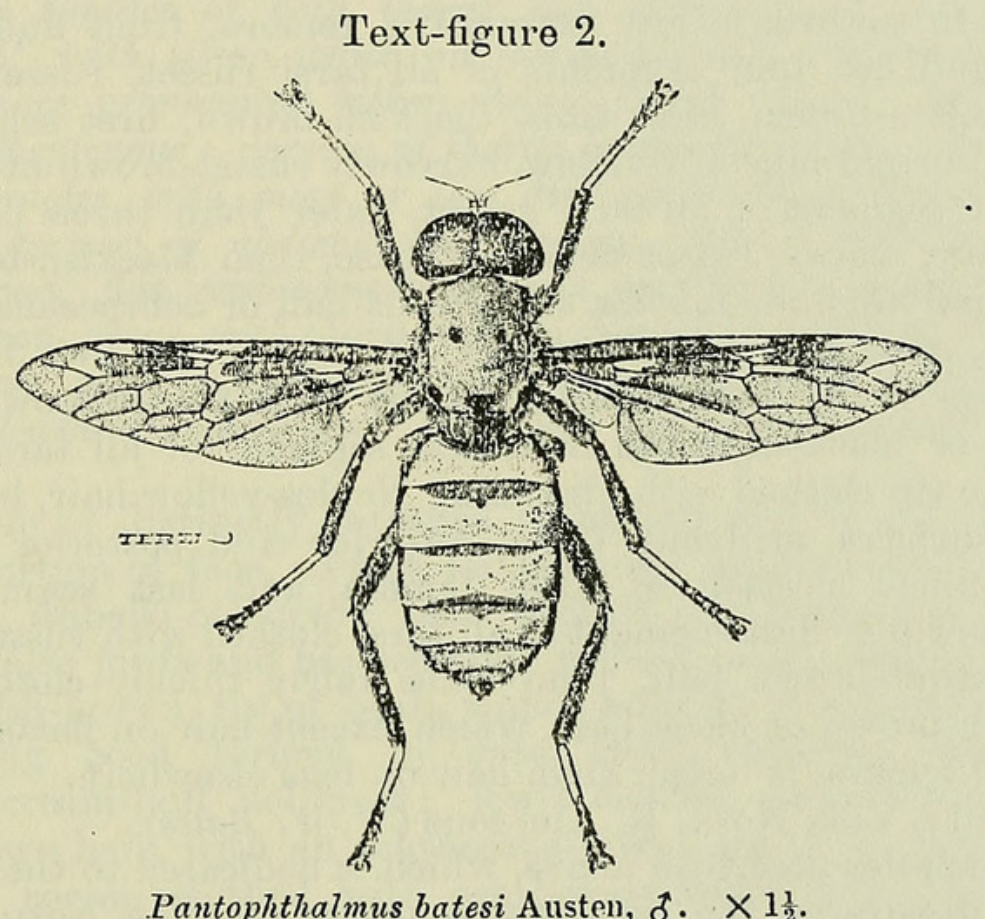

while its hind margin, which exhibits a backwardly directed projection in middle line, is more or less brace-shaped; lateral extremities of tergites clothed on dark areas with dark brown or blackish-brown hair, and elsewhere clothed with yellowish, cinnamon-coloured, or brownish hair, remainder of dorsum clothed with minute, scattered, ard very inconspicuous cinnamon-buft hairs, which on sixth tergite are somewhat longer; venter orange-buff, partially suffused with a silvery sheen (especially distinct on first three sternites), and sparsely clothed with hair similar in colour to that on dorsum, but longer. Wings light sepia-coloured, marked as shown in fig. 2, the most conspicuous markings being those on the costal border, consisting of two irregularly shaped dark blotches and two cream-buff or pinkishbuff marks; of the latter, the one nearer the base of the wing, 
which extends from the costa to the upper distal angle of the second basal cell and includes the anterior transverse vein, resembles the corresponding mark in the wing of $P$. tabaninus 'Thunb., but is more sharply defined; the veins separating the second posterior marginal cell from the discal cell, and the fifth posterior marginal cell from the second basal cell are each enclosed in a sharply defined, cream-buff spot; a faint, elongate, cream-buff spot is visible on the sixth longitudinal vein, in the centre of the lower margin of the anal cell, and both basal cells are cream-buff at the base; veins sepia-coloured, except in the lighter areas where they are cinnamon-buff or pinkish-buff, first longitudinal vein where enclosed in more distal of the two dark costal areas, and fifth longitudinal vein except at base and tip of second basal cell, darker than most other veins or portions of veins. Halteres cinnamon-buff. Legs: hind femora slightly incrassate towards distal extremity; femora, front and middle tibiæ, and last four segments of all tarsi russet, russet-brown. or chocolate-brown, hind tibiæ blackish-brown, first segment of all tarsi bright mustard-yellow, narrowly russet-brown at extreme tip, last segment of all tarsi russet, paler than three preceding segments; claws russet-brown at base, then blackish-brown or black; pulvilli and empodia ochraceous-buff or ochraceous-tawny ; femora, front and middle tibire, and second and two following segments of all tarsi clothed mainly with russet-brown, darkbrown, or blackish-brown hair, first segment of all tarsi except extreme tip clothed with glistening Naples-yellow hair, inner and flexor surfaces of front tibiæ, anterior and posterior surfaces of proximal portion of hind femora, and last segment and extreme tip of first segment of all tarsi clothed with russet-brown or chestnut-brown hair, hind tibir fairly thickly clotherl with blackish-brown or black hair, which, except hair on flexor surface of hind femora, is longer than hair on leg's elsewhere.

Brazil: Villa Nova, R. Amazons ( $H$. W. Bates).

The species described above, which is dedicated to the memory of its discoverer, the well-known author of 'The Naturalist on the River Amazons,' is readily distinguishable from any of its congeners included in the present paper. From $P$. tabaninus Thunb., in addition to the points of difference to which special attention has been shown in the foregoing description, P. batesi is separable, inter alia, owing to its unstriped thorax, and, at any rate in the $\sigma$ sex, the silvery sheen on the dorsum of the abdomen. From the two following species, in both of which, at least in the $\sigma$, the dorsum of the abdomen is likewise "silverwashed," P. butesi may be distinguisher in the same sex, inter. alia, by its abdomen being narrower and spotted with black along the lateral margins. From $P$. hellerianus Enilerl., of which a re-description is given below, $P$. batesi is further distinguishable, owing to its much more clearly marked wings, to the presence of dark spots on the thorax, and to the surface of the latter not being silvery. 


\section{Pantophthalmus hellerianus, Enderl. (Text-fig. 3.)}

Acanthomera helleriana Enderlein, Zool. Anz., Bd. xliv. no. 13, p. 581 (July 28, 1914).

Since the original description of this species, which is at present only known in the male sex, in some respects requires amplification, $P$. hellerianus Enderl. is redescribed below. In the case of the specimen in the National Collection, at any rate, the brown or greyish-brown, $\mathbf{W}$-shaped mark on the dorsum of the thorax, on which Enderlein lays stress, is only visible when the insect is viewed at a fiirly low angle from behind, and even then it is not very distinct.

o.- - Length (one specimen) $29.5 \mathrm{~mm}$; width of head $8.4 \mathrm{~mm}$.; greatest width of abdomen (across third tergite) $12.2 \mathrm{~mm}$.; length of wing $23.2 \mathrm{~mm}$.

Dorsal surface of both thorax and abdomen, at least in o, "washed" with silver, which on thorax is duller, but on abdomen has a more pronounced silken sheen; facial "beak" very small and inconspicuous; dorsum of thorax (scutum), when viewed from certain angles, with more or less distinct traces of longitudinal stripes; dorsum of abdomen unicolorous, without definite lateral spots, broad, flat, and somewhat ovate pyriform in outline when viewed from above, with sharp edges to third and following tergites; wings pale, with (except when vievved against a dark background) faint, ill-defined markings; hind legs with a small subfemoral spine.

Head in $\sigma^{*}$ distinctly flattened in antero-posterior direction; upper portion of face, except immediately adjacent to bases of antennæ, isabella-coloured; remainder of face, including base of beak, as also jowls and basioccipital region, dark mummy-brown or blackish-brown, tip of beak, which scarcely protrudes beyond enveloping hood formed by base, chestnut-brown, shining; occiput cream-buff pollinose; jowls clothed with brownish or dark brown hair, with an ochraceous-tawny gleam at base, basioccipital region clothed with ochraceous-tawny hair; first and second segments of palpi greyish cinnamon-brown, clothed with dark brown hair, terminal segment tawny or cinnamon-rufous, curved, slender, and tapering; first segment of antennce mummybrown, second segment tawny, fringed below with minute, ochraceous-buff hairs (third segment missing in specimen described). Thorax: dorsum of main portion (scutum), when viewed at an angle from behind, exhibiting a pair of admedian, darker (shimmering greyish-olive), longitudinal stripes, commencing on fore border, converging and diminishing somewhat in width as they proceed backwards, and becoming narrower and indistinct after passing transverse suture; posterior portion of scutum with a similar, median, longitudinal stripe, commencing in prescutellar groove and tapering off and disappearing about halfway between latter and transverse suture; dorsum of scutum clothed with fine yellowish bair; scutellum, which, except on anterior angles, is 
mainly sepia-coloured, clothed with similar hair; outer extremities of humeral calli cinnamon-rufous, shining, a ridge of fairly long, shining, tawny-olive or cinnamon-buff hair on each side of dorsum, connecting humeral with corresponding postalar callus, postalar calli mainly mummy-brown, clothed with similarly coloured hair; pleuræ and pectus mummy-brown, clothed with hair of similar colour, a tuft of bright ochraceous-tawny hair on each side, in prothoracic region. Abdomen: ground-colour of dorsum russet, lateral extremities of first tergite broadly, and those of fourth tergite narrowly sepia-coloured, anterior angles of second and third tergites similarly tinted; first tergite clothed with fine cinnamon-buft hair, longer and more conspicuous on lateral

Text-figure 3 .

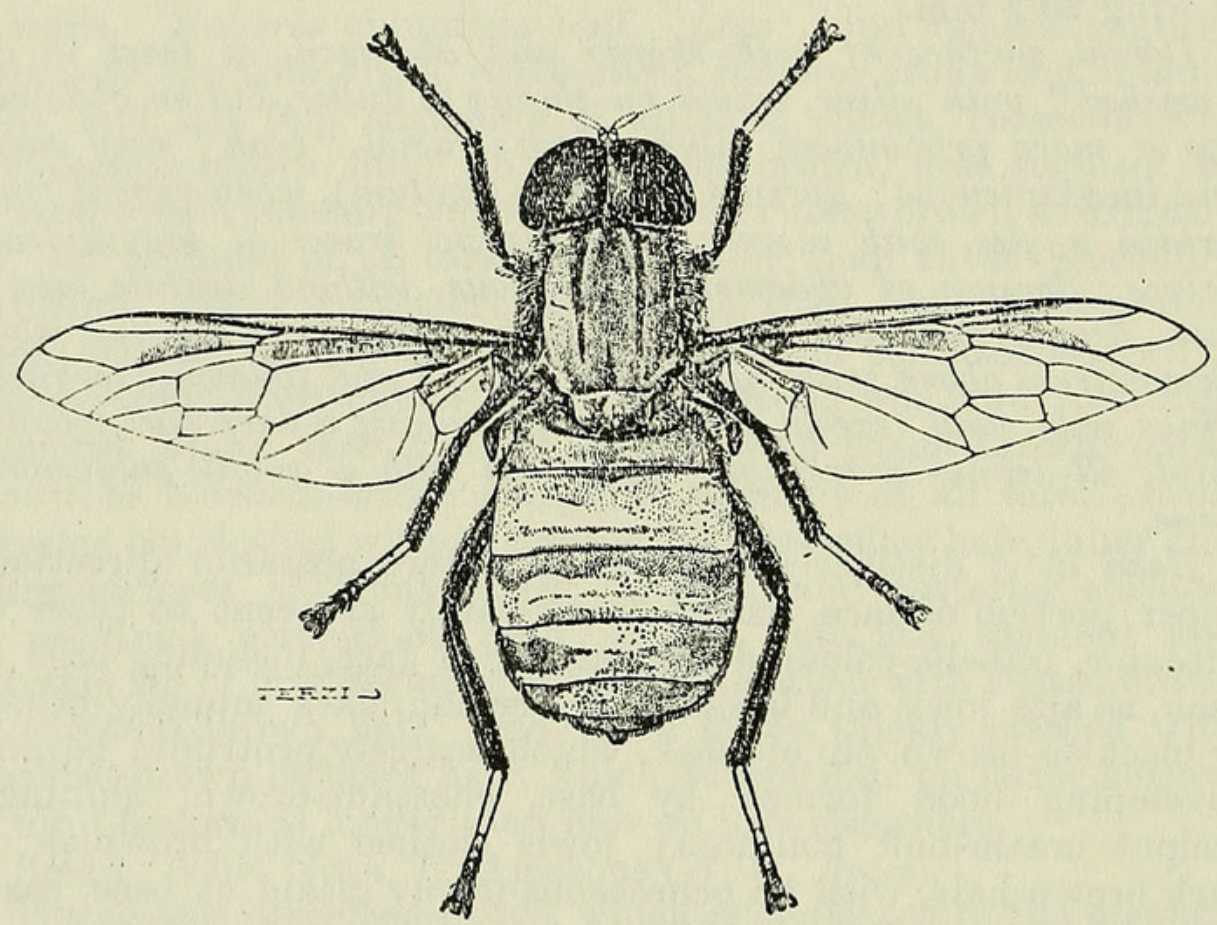

Pantophthalmus hellerianus Enderl., $\delta . \times 1 \frac{1}{2}$.

extremities, where, except on anterior angles, it has an ochraceous-tawny tinge; lateral extremities of second tergite clothed with fine, short, appressed, cinnamon-buff hair (sepia-coloured area occupying each anterior angle clothed with shining cinnamon-brown hair); lateral extremities of third and two following tergites fringed with cinnamon-brown hair; sixth tergite largely clothed with similar hair, which is longer on hind border; venter uniformly tawny. Wings pale mouse-grey, first costal and subjacent cell mummy-brown or sepia-coloured, two dusky (duskydrab), more or less quadrate blotches on costal border, separated by cream-buff interspaces; proximal blotch including rather less than distal half of first basal cell, but not extending to tip of latter; distal blotch, which in specimen described at least is the darker of the two, including distal sixth or seventh of first 
longitudinal vein, and area immediately below as far as third longitudinal vein ; tip of wing, including distal portion of first submarginal and entire second submarginal cell, except its extreme base, somewhat darker than hind border (when viewed against a light background), and separated from distal costal blotch by an ill-defined and irregular pale area ; costa ochraceoustawny or light cinnamon-brown (mummy-brown at base and above distal costal blotch), remaining veins cinnamon-brown, ochraceous-tawny or ochraceous-buff (in darker areas corresponding in tint to adjacent membrane). Halteres: stalks cinnamon-buff, knobs blackish-brown. Legs : hind femora of uniform thickness (not incrassate towards distal extremity); femora and tibiæ russet-coloured, clothed with fine, dark brown hair, flexor surfaces of front tibiæ clothed with short, glistening, ochraceoustawny hair; first segment of front and middle tarsi ochraceousbuff (cinnamon-brown at extreme tips on flexor surface), first segment of lind tarsi cream-buff (light cinnamon-brown at extreme tips on flexor surface), last four segments of all tarsi ochraceous-tawny, clothed with minute, appressed hairs of similar colour; claws rufous-tawny at base, then black; pulvilli and empodia ochraceous-butf.

One $\delta$, Brazil : R. Amazons (precise locality unknown) (H.W. Baies).

Pantophthalmus hellerianus, which, in the of sex at any rate, agrees with $P$. argyropastus Big., in having the dorsal surface of the abdomen silvery, is readily distinguishable from that species, inter alia, by the dorsum of the main portion of the thorax being not only much paler but also devoid of dark spots ( $c f$. notes on $P$. argyropastus below). For distinctions from $P$. batesi Austen, vide supra, p. 568.

Finally it may be added that the example of $P$. hellerianus in the National Collection exhibits, on the dorsal surface of its abdomen, several specimens of the pseudo-parasitic Acarid mentioned in the present paper in connection with $P$. tabaninus Thunb., and other species; in this case there is also a number of very much smaller mites on the dorsum of the thorax.

\section{Pantophthalmus argyropastus Big.}

Megalomyia argyropasta Bigot, Ann. Soc. Ent. Fr., 5 Sér., T. x., Bulletin, p. v (1880).

Megalemyia argyropasta Bigot, Ann. Soc. Ent. Fr., $6^{\mathrm{e}}$ Sér., T. i. pp. 455,458 (1881).

An examination of the holotype male of this species, formerly in the Bigot collection and presented to the British Museum (Natural History) by Mr. J. E. Collin, F.E.S., shows that, in spite of Bigot's misleading statement to the effect that the thorax is narked with "three, somewhat indistinct, blackish bands," the dorsum of the main portion of the thorax (scutum) is actually unicolorous, with scarcely a trace of longitudinal stripes, but 
spotted as in P. batesi Austen, that is to say, with a pair of small, blackish-brown, admedian spots on the transverse suture, a large seal-brown blotch in front of the scutellum, and the postalar calli similarly marked; the humeral calli are pale drab-grey pollinose above. The dorsum of the main portion of the thorax being dark brown, with a thin, smoke-grey, faintly silvery, pollinose covering, clothed with fine, cinnamon-buff or drabcoloured hair, the general appearance of this part of the body resembles that of moleskin. The dorsum of the abdomen, which is unicolorous and, when viewerl at an angle from behind, appear's dull Mars-brown, has a bright silvery sheen when regarded from other directions.

Pantophthalmus argyropastus is one of the smaller representatives of its genus, the type, which is from Panama, measuring only $24.5 \mathrm{~mm}$. in length.

\section{Pantophthalmus versicolor, sp. n. (Text-fig. 4.)}

б.--Length (three specimens) 27 to $30 \mathrm{~mm}$.; width of head $7 \cdot 75$ to just over $8 \mathrm{~mm}$.; greatest width of abdomen (across third tergite, exclusive of fringe of hair) 12.2 to $14.25 \mathrm{~mm}$.; length of wing $22 \cdot 25$ to $24 \cdot 6 \mathrm{~mm}$.

Medium-sized species, with smallish head, which is distinctly flattened antero-posteriorly, striped thor ax, and (at any rate in o) vivid ferruginous or orange-rufous, sharp-edged abdomen; facial tubercle or "beck" in o" either indistinguishable, its position mar.ked by a pit, or minute and vestigial; abdominal tergites without lateral spots, though basal angles of first tergite extersively, and those of second tergite narrowly, mummy-brown; wing-markings in o resembling those in same sex of P. tabaninus Thunb.; hind femora of uniform thickness, without a spine on under surface, and with terminal spine represented only by a blunt projection.

Meacl: face and jowls mummy-brown, a transverse, horizontal, smoke-grey, pollinose streak on front margin of jowls connecting each eye with buccal cavity; occiput greyish-olive, posterior orbits silvery-white pollinose; jowls clothed with mummy-brown hair, which is shining ferruginous at base; first and second segments of palpi clove-brown, clothed, like the terminal segment except distal extremity of latter, with brownish-ferruginous hair, terminal segment russet (brownish at base), cylindrical, straight, bluntly pointed at distal extremity; antennce in $\delta$ lighter or darker cinnamon-brown (terminal style ochraceoustawny), third (compound) segment viewed from side bluntly lanceolate in outline, second segnient midway between base and distal extremity bearing a circlet of short, sparse, cinnamonbrown or ochraceous-tawny hairs. Thorax: ground-colour of dorsum of scutum mummy-brown or olive-brown; dorsum smokegrey or pale smoke-grey pollinose in front, on humeral calli, lateral margins, lateral expansions of transverse suture, and on postalar calli ; central region of dorsum bearing three conspicuous, dark, converging, longitudinal stripes (approximately equal in 
breadth, except that outer stripes are usually somewhat broader in front), extending from fiont to hind margin, but confluent posteriorly after passing transverse suture, outer stripes black or blackish-brown, median stripe paler, dark mummy-brown, sometimes less noticeable than outer stripes; behind transverse suture a short blackish-brown or dark brown longitudinal stripe on each side, extending from suture to postalar callus, and on inner side of this stripe a somewhat oblique, shining, chestnut-brown stripe ; dorsum, except main portion of upper surface of scutellum, which is bare, thickly clothed with fine, silky, glistening, reddish-brown, ochraceous-tawny or tawny-olive hair, which on lateral borders is longer than elsewhere; scutellum mummy-brown, dark seal-brown, or russet-brown, more or less distinctly shimmering silvery-white

Text-figure 4.

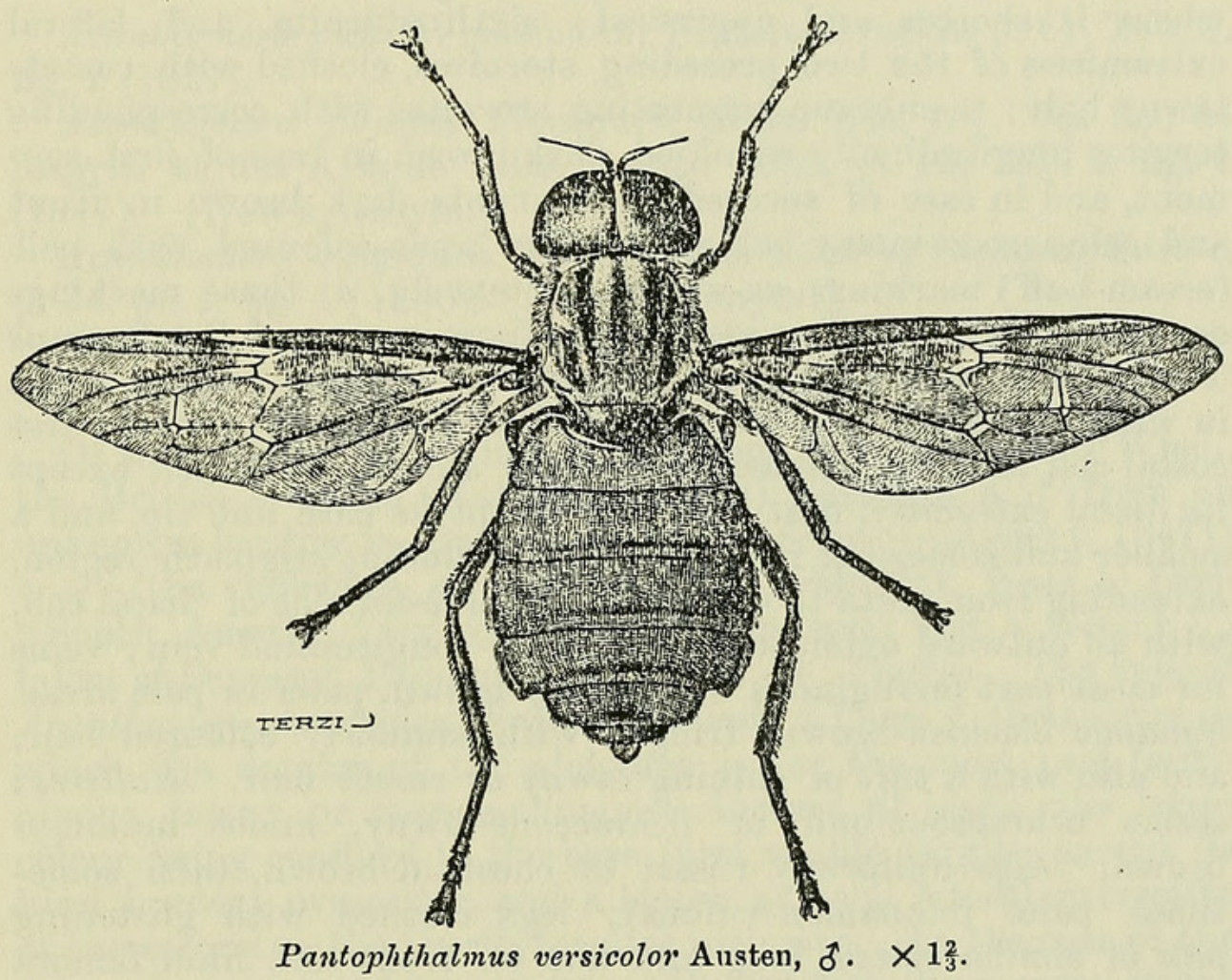

or shimmering smoke-grey pollinose above, except on hind border; pleuræe and pectus chocolate-brown or warm sepia-coloured, clothed with fine and fairly long, dark brown or reddish-brown hair. Abdomen: second and two following tergites each with a reddish-brown transverse band, just in front of hind margin and widely separated from lateral extremities in each case, posterior half of fifth tergite with an ill-defined blotch of similar colour in centre, not reaching hind margin; first tergite thinly clothed with fine hair, which is ochreous and recumbent except on basal angles where it is brownish and erect; second and three following tergites sparsely clothed with minute, appressed, glistening, ochraceous-tawny hairs, which in the case of second and 
third tergites at any rate are only noticeable on close scrutiny, sixth tergite clothed with longer hair of similar colour; lateral extremities of second tergite, except posterior angles, clothed with dark brown or brownish hair, those of third and fourth tergites fringed with longer, outstanding, closely set, shining, cinnamon-rufous or russet-tawny hair, lateral extremities of fifth tergite with a shorter, thinner, and paler fringe of similar character; first sternite mummy-brown or sepia-coloured (hind border smoke-grey or drab-grey pollinose), clothed with fine and fairly long, erect, dark brown hair; remaining sternites sepia-coloured, lateral extremities of third and following sternites paler (ochraceous-tawny); second and two following sternites (except lateral extremities of third and fourth), and central portion of fifth sternite thinly clothed with fine, dark brown hair, which on second sternite, at least anteriorly, is longer and erect, but elsewhere is shorter and appressed; sixth sternite, and lateral extremities of the two preceding sternites, clothed with russettawny hair; membraue connecting sternites with corresponding torgites longitudinally wrinkled, dark brown in case of first segment, and in case of succeeding segments dark brown in front and ochraceous-tawny behind. Wings sepia-coloured, with pale (cream-buff) markings as shown in text-fig. 4, these markings occupying corresponding positions to those in wing of $P$. tabaninus Thunb., but somewhat more restricted in extent; darkest areas in wing are those which are usual in this family, namely first costal cell and cell immediately below, second costal cell except its distal extremity, first basal cell except its base and tip, and a sinaller and somewhat ill-defined area including stigmatic region, extending from costa to distal half or three-fourths of discal cell, with an outward extension along third longitudinal vein; veins for most part ferruginous or mummy-brown, paler in pale areas. Squance blackish-brown, fringed with similarly coloured hair, and also with a tuft of shining tawny or russet hair. Halteres : stalks ochraceous-buff or ochraceous-tawny, knobs mummybrown. Legs uniformly russet or chestnut-brown, tarsi sometimes paler (cinnamon-rufous); legs clothed with glistening hair of similar colour, long and fine on front and hind femora short elsewhere, hair on fernora sometimes appearing dark brown, sometimes tawny; claws orange-cinnamon or russet, their distal extremities black; pulvilli and empodia ochraceous-buff or orange-buff.

Guatemala and Mexico. Holotype, Pancina, Vera Paz, Guatemala (G. C'. Champion); two paratypes, Cuesta de Misantla, Mexico (M. Trujillo). The holotype is the specimen briefly described, but not named, by Osten Sacken (Biol. Centr.-Amer., Dipt. i. p. 68).

Through the kindness of Mr. J. E. Collin, the British Museum (Natural History) has received a solitary $\delta$ of this species, which unfortunately is in poor condition and is without a locality label. In the Bigot collection, whence it was taken, this fly was 
associated with two of of $P$. tabaninus Thunb. and all three specimens stood above the label "Acanthomerc seticonnis Wied. o"," in Macquart's handwriting (vide supra, p. 563).

In the male sex, at any rate, Pantophthalmus versicolor, by means of the characters mentioned in the diagnosis printed in italics above, is readily distinguishable from any of its congener's at present known. From the male of P. tabaninus 'Thunb., for which at the tirst glance it might possibly be mistaken, the male of the present species can be distinguished at once owing to its smaller and differently shaper head, duskier and differently striped thorax, and broader and flatter, sharp-edged abdomen, the sides of which are devoid of white spots, and are not black on the basal half.

\section{Pantophthalmus pictus Wied.}

Acanthomera picta Wiedemann, Diptera Exotica, p. 61, Tab. ii. fig. 2 (1821).

Acanthomerc flavipes Macquart, Mém. Soc. roy. des Sc., de l'A gric. et des Arts de Lille, Année 1846, p. 42, 'Tab. i. fig. 2 (1847). [New synonym.]

Acanthomera magnifica Waller, Ins. Saund., Diptera, Part i. p. 74 , pl. 1. fig. 1 (1850). [New synonym.]

Acanthomera teretruncum Fiebrig, Zeitschr. f. wiss. Insektenbiol., Bd. ii. pp. 345-347, figs. 17-19 (1906).

Of this species, which is the genotype of Acanthomera Wied., the British Museum (Natural History) possesses a $\delta$ from an unknown locality in Brazil (purchased from - Argent, 1847); ¿ $q$ (the holotype of Acanthomera magnifica Walk.), from "South America" (ex coll. W. W. Saunder's); and a second $q$, taken at Sapucay, Paraguay, 21.i.1905 (W. Foster). The type of Acanthomera magnifica Walk. represents a form of the species in which the dorsum of the abdomen is for the most part ferruginous, tawny, or orange-cinnamon instead of black, the latter colour being confined to the base (first visible tergite, except its hind border), ovipositor, and a blotch at each lateral extremity of the second to the fourth tergites inclusive. In the case of the type of $A$. magnifica, moreover, the whitish transverse streak near each posterior angle of the third ventral scute is wanting, but this is doubtless due to individual variation.

From the Bigot collection, thanks to the generosity of Mr.J. E. Collin, the National series has been enriched by the type of Acanthomera flavipes Macq. (stated by Macquart--loc. cit.- to be from Brazil), and two other $q$, 9 , all of which unfortunately are without locality labels. In the case of Macquart's type the abdomen is russet-brown ("brun vineux," apud Macquart, loc. cit.), a fact which misled Enderlein (Zool. Anz., Bd. xli. p. 101 (1912)) into treating $A$. flavipes Macq. as specifically distinct from A. picta Wied. Enderlein, however (t. cit. p. 105), is perfectly correct in regarding $A$. teretruncum Fiebrig as a synonym of 
A. pictı Wied., and indeed, so long ago as 1908, the present writer placed a manuscript note in the Museum collection drawing attention to this identity.

The species under discussion is represented in the Hope Department of the Oxford University Museum by two $q q$, one of which is of ordinary size (total length, including ovipositor and facial beak, $41.2 \mathrm{~mm}$.; wing-expanse $73 \mathrm{~mm}$.), while the other is a diminutive example, with dimensions (total length, including ovipositor and facial beak, $29 \mathrm{~mm}$.: wing-expanse $50.5 \mathrm{~mm}$.) much below normal. Both specimens are unfortunately without locality labels ; the larger of the two is labelled "Miers coll.," while the other, probably collected by Bates on the Amazons, bears a label in Westwood's handwriting, with the words "E Mus. Saunder's. 1867."

In the wing-marking of Pantophthalmus pictus a characteristic feature is a broad, lark brown, L-shnped blotch, the shorter arm of which meets the costa in such a way as to include the tip of the mediastinal vein, while the longer arm embraces the third longitudinal vein between the anterior transverse vein and the bifurcation of the former, without being in contact with either.

Fiebrig's interesting observations on the preliminary stages and bionomics of "A. teretruncum" have already been referred to (vide supra, p. 556 ).

\section{Pantophthalmus chuni Enderl.}

Acanthomera chuni Enderlein, Zool. Anz., Bd. xli.' no. 3, pp. 102, 103, fig. 4 (December 20, 1912).

This fine species-described by its author from two $q$ 우 from Peru, in the Zoological Museum, Stettin--is represented in the National Collection by a single of from Brazil (R. Amazonsprecise locality unknown: $H$. $W$. Bates), measuring $42 \mathrm{~mm}$. in length from the tip of the prominent facial beak to the end of the ovipositor, and having a wing-expanse of $70.6 \mathrm{~mm}$. On the second and third abdominal tergites, conspicuous against the velvety-black or sooty-black ground-colour, are half-a-lozen specimens of the Acarid parasite already noticed in connection with several other species.

By the courtesy of Dr. Hugh Scott, the writer has been permitted to examine a $q$ of this species in the University Museum of Zoology, Cambridge. Except that its dimensions (length from tip of facial beak to end of ovipositor $29 \mathrm{~mm}$., wing-expanse $53.75 \mathrm{~mm}$.) are much below normal, this example, which was likewise taken on the River Amazons (Nevile Goodman, 1879), agrees with that already mentioned.

In spite of certain apparent discrepancies, there can be no doubt as to the correctness of the identification of the Brazilian specimens referred to above. The description of $P$. (Acanthomera) chuni furnished by Enderlein is seriously misleading in more than one respect. In the first place the German author speaks of the 
face as being "very broad and very greatly widened in front"; a comparison, however, of the British Museum specimen with examples of other species shows that the ㅇ of $P$. chuni is in no way abnormal in this respect. Secondly, both in the diagnostic table on p. 102 (loc. cit.) and in the detailed description on the following page, Enderlein speaks of a single, relatively narrow thoracic stripe. On the other hand, in actual fact, not only does the dorsum of the thorax exhibit the three dark thoracic stripes so constantly seen in representatives of the family Pantophthalmidx, but, even regarding the thorncic markings as consisting of a single stripe, bearing on its surface a pair of paler, admedian stripes, the measurements given by Enderlein himself, which agree in detail with the corresponding measurements taken from the British Museum specimen, show that as a characterization "relatively narrow" is entirely unwarranted.

\section{Pantophthalmus conspicabilis, sp. n. ('lext-fig. 5.)}

ㅇ.--Length (one specimen), including ovipositor and facial beak, $42 \mathrm{~mm}$.; width of head $10.5 \mathrm{~mm}$.; width of front at vertex $1.8 \mathrm{~mm}$. (immediately above base of antennæ just under $2 \mathrm{~mm}$.); length of facial beak just under $3 \mathrm{~mm}$; greatest width of abrlomen (across third tergite) just under $16 \mathrm{~mm}$.; length of wing $31.5 \mathrm{~mm}$.

In $q$ sex, at least as represented by typical specimen, a grey and black species, with prominent, sharp-pointed facial beak; almost parallel-sided front; conspicuously striped thorax; blunt-edged abdomen, which on dorsal surface, on each lateral border, bears two conspicuous silvery-white spots and a fringe of short hair; wings marbled with sepia and light buff, somewhat resembling those of Pantophthalmus (Acanthomera) chuni Enderl., but differing in details of pattern; and with hind femorc incrassate towards tips, and bearing a small spine on under surface and a large terminal spine.

Head: face and jowls sepia-coloured or mummy-brown, inner margin of ench eye bounding fnce with a narrow, smoke-grey, pollinose edging, which above sends off an extension to meet base of facial beak, while below a similar but silvery-grey extension connects pollinose edging of eye with buccal cavity; facial beak long and sharp-pointed, its expanded basal portion dark brown above, russet-brown on sides below, the shining tip blackishbrown; front (frons) of moderate width, and only very slightly broader at its anterior extremity than at vertex; front and occiput, incluling posterior orbits, uniformly olive-buff or pale olive-buff pollinose, except that the conspicuous ocellar tubercle, which is distinctly separated from vertical margin of occiput, is mummy-brown, and that in certain aspects, at least in typical specimen, behind ocellar tubercle, on vertical margin of occiput, and also on central anterior portion of front, above base of antenna, ground-colour shows through pollinose 
covering, and appears more or less tawny or ochraceous-salmoncoloured; upper portion of occiput, except posterior orbits, clothed with fine, ochraceous-buff hair, basioccipital region and lower portion of occiput, except posterior orbits, clothed, like jowls, with fine, brownish or dark brown hair ; first and second segments of palpi dull tawny-olive (second segment dark brown shortly before distal extremity), clothed on sides and below with blackish hair which is longer towards tip of second segment, distal segment russet-coloured with a thin greyish-pollinose covering, cylindrical and acuminate, considerably thicker than base of proximal segment, but less swollen than is typically the case in the genus Rhaphiorhynchus, distal segment at base and on outer surface bearing a few short black hairs; antenne in $q$ $5.6 \mathrm{~mm}$. in length in case of type, agreeing generally in shape, and in form and relative dimensions of the eight divisions of the third (compound) segment, with antenna of Pantophthalmus (Acanthomera) chuni Enderl., + , as figured (Zool. Anz., Bd. xli. no. 3, p. 104, fig. 4 , December 20,1912 ) by its author; first and second segments of antennæ mummy-brown, distal extremity of second segment sparsely fringed with short, ochreous hairs, proximal division of third segment mummy-brown, next six divisions tawny, terminal (elongate and attenuate) division paler (pinkish-cinnamon), entire antennæ, when viewed from certain angles, clothed with a thin, silvery-grey, pollinose covering. Thorax: dorsum of main portion (scutum) silvery-grey (a deep border on each side, extending from humeral to postalar calli inclusive, silvery), median area in front of transverse suture when viewed from certain angles tinged with pinkish-cinnamon (at least in case of type), owing to ground-colour showing through ; from inner end of each humeral callus a conspicuous, blackishbrown longitudinal stripe extends backwards, each stripe being fairly broad in front and diminishing in width as it passes back, until at a point about one-third of the distance between transverse suture and prescutellar groove it becomes suddenly attenuate, and is thence continuer as a narrow extension as far as the prescutellar groove, in front of which it is connected with its fellow ; attenuate portion of blackish-brown longitudinal stripes 'scarcely noticeable from certain angles, and completely visible only when insect is viewed at a low angle from behind; in middle line, between the two blackish-brown stripes, is an incomplete, paler (brownish-drab) longitudinal stripe, which, commencing as a deltoid expansion resting upon posterior commissure between the attenuate ends of the blackish-brown stripes, extends forwards, disappearing (in case of type, at least) before reaching transverse suture, but reappearing on level of latter, and tapering to a point and terminating between humeral calli; on upper margin of lateral silvery border on each side, between inner extremities of humeral and postalar calli, is a narrow, longitudinal brownish streak, which, following configuration of thorax, curves outwards in front of transverse suture, and makes 
a similar but rather flatter curve behind it; scutellum mummybrown (posterior border, which is thickly covered with small, polished, rounded tubercles, mainly blackish-brown), lateral extremities of dorsal surface silvery-grey; dorsum of scutum clothed with fine, short, silky, yellowish or brownish hair, which becomes longer on hind border; scutellum, except anterior half of dorsal surface, which is bare, clothed with short, dark brown or blackish-brown hair; pleurre and pectus mummy-brown (appearing darker when viewed from certain angles), clothed with fine, dark brown hair. Abdomen (at least in case of type, and except as regards the lateral silvery-white spots) uniformly blackish-brown or brownish-black above and below (ventral surface perhaps rather more brownish than dorsal); second and

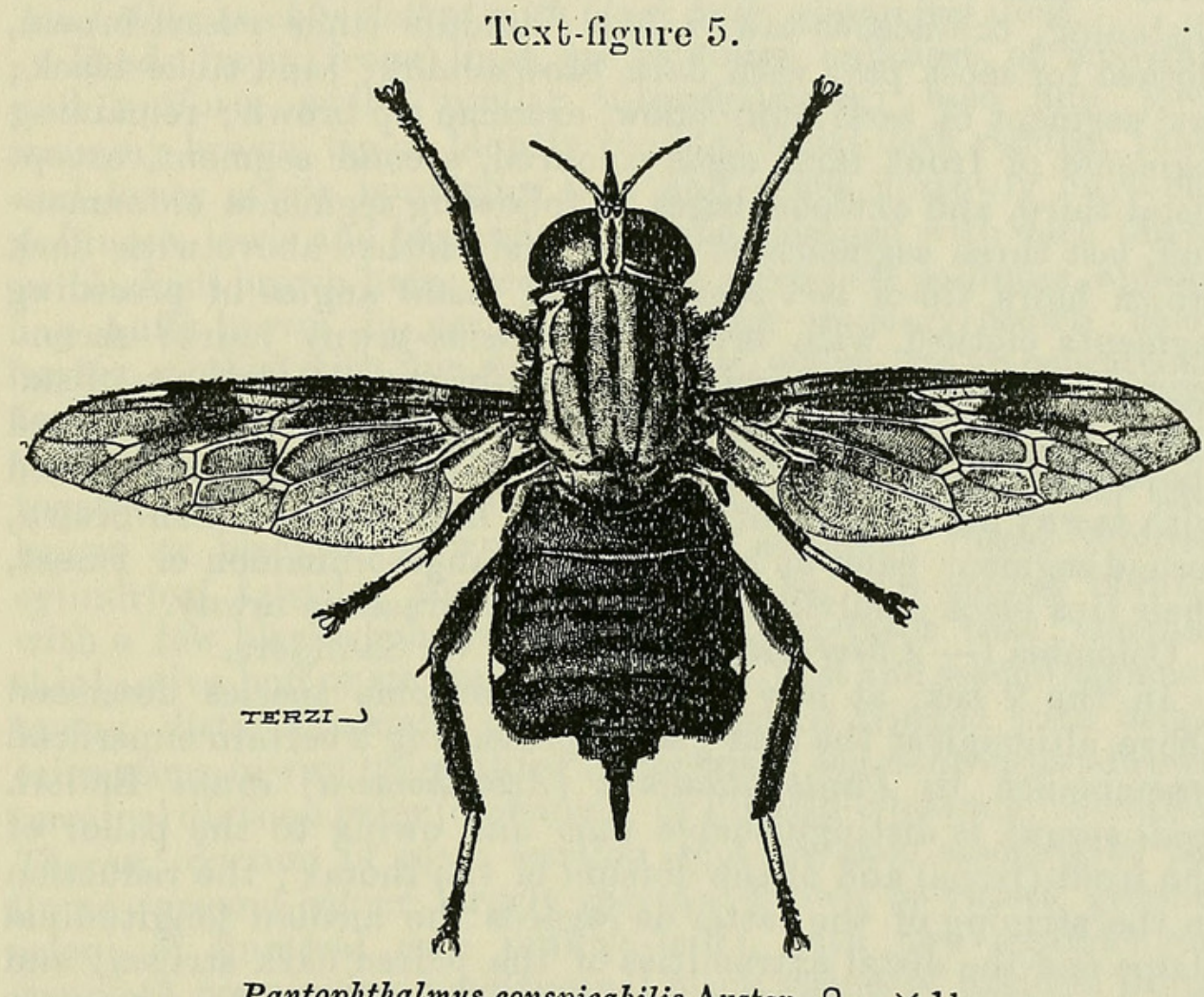

Pantophthalmus conspicabilis Austen, ㅇ. $\times 1 \frac{1}{6}$.

third tergites each with a conspicuous, silvery-white spot on each side, close to posterior angle; lateral borders of dorsum clothed with blackish-brown hair, which on second and two following tergites forms a not very conspicuous fringe on each side (on lateral margins of fourth tergite the fringe is longer and sparser than on the two preceding tergites); first sternite, and central area of second, clothed with fine, dark brownish hair. Wings marked as shown in text-fig. 5, the dark blotches on costal border sharply defined and conspicuous; veins sepia-coloured or cinnamon-brown, in pale areas usually paler (pinkish-cinnamon). Halteres: stalks cinnamon-brown, knobs blackish-brown. Legs: front femora with a small but distinct terminal spine, which on

Proc. Zool. Soc.-1923, No. XXXVIII. 
middle femora is represented by a blunt triangular projection; hind legs with a very small, somewhat blunt and triangular, subfemoral spine; terminal spine on hind femora large, long ( $1 \mathrm{~mm}$. in length) and sharp; length of hind femur (exclusive of terminal spine) $15.6 \mathrm{~mm}$; ; hind femora distinctly thickened towards distal extremity, clothed with fine, short, blackish hair, which is longer on flexor surface and, owing to greater density, especially noticeable between subfemoral spine and tip, distal extremities of extensor and posterior surfaces clothed mainly with bright, appressed, russet-coloured hair; hind tibiæ thickly clothed with fine, black hair, longer than elsewhere on extensor surface, where it forms a conspicuous fringe; femora reddish-brown, darker towards distal extremities, tips of hind pair reddish-brown; front tibiæ russet-coloured, clothed on flexor surface with short, g]istening, ochraceous-tawny hair; middle tibir russet-brown, clothed for most part with dark brown hairs; hind tibice black; first segment of tarsi buff-yellow, extreme tip brown; remaining segments of front tarsi sepia-coloured, second segment, except distal third, and extreme bases of following segments cinnamonbuff, last three segments of front tarsi clothed above with dark brown hairs, tip of last segment and distal angles of preceding segments clothed with bright ochraceous-tawny hairs; second segment of middle tarsi cinnamon-brown, darker at distal extremity, last three segments of middle tarsi dark brown, clothed above with similarly coloured hair, tip of last segment clothed with tawny hair; last four segments of hind tarsi blackish-brown, second segment paler at base ; claws orange-cinnamon or russet, their tips black; pulvilli and empodia ochraceous-tawny.

Colombia (-Chevrolat): ex coll. W. W. Saunders.

In the $q$ sex, at any rate, the handsome species described above, although at the first glance presenting a certain superficial resemblance to Pantophthalmus (Acanthomera) chuni Enderl. (vide supra), is distinguishable inter alia owing to the pallor of the front (frons) and of the dorsum of the thorax; the reduction in the striping of the latter as regards the median longitudinal stripe and the distal extremities of the paired dark stripes; and the shorter, much more densely hairy and consequently apparently stouter hind tibiæ. In the case of the type, at least, of $P$. conspicabilis, as compared with the specimen of $P$. chuni referred to on p. 576, the lateral silvery-white spots on the dorsum of the abdomen are blunter and rounder.

'This species is in any case closely allied to, and may ultimately prove to be identical with, Pantophthalmus kertészianus (Acanthomera kertésziana) Enderlein, described (Zool. Anz., Bd. xliv. no. 13 , p. 578, July 28,1914 ) from two $q$ o from Peru, in the Museums of Budapest and Stettin. Since, however, Enderlein ( $t$. cit. p. 579), in describing the wing in $P$. kerteszianus, says that the "basal fourth and a large spot on the anterior margin" are "pale ochreous," it seems wiser, provisionally at any rate, to regard $P$. conspicabilis as distinct. 


\section{Pantophthalmus conspicuus, sp. n. (Text-figs. 6, 7.)}

‥-Length (one specimen), including ovipositor and facial beak, $36.2 \mathrm{~mm}$.; width of head $9.4 \mathrm{~mm}$.; width of front at vertex $1.8 \mathrm{~mm}$; greatest width of abdomen (across third tergite) $14.5 \mathrm{~mm}$.; length of wing $28 \mathrm{~mm}$.

In ㅇ sex, at least in case of typical specimen, a grey, honeyyellow or iscubella-coloured (probably in life green) and black species, with facial beal represented by a blunt, rounded prominence, conspicuously black-striped thorax, blunt-edged abdomen, and no subfemoral spine on hind legs; lateral borders of first four abdominal tergites black, with two large, silvery-white spots on each side; wings marked as shown in text-fig. 6, broadly cream-buff or buff-yellow at base; hind femora somewhat incrassate towards tips, hind tibia thickly clothed with black hair, appearing stont.

Head: front (frons) light greyish-olive pollinose, of moderate and uniform width, ocellar tubercle black; face and jowls mummy-brown, tip of bluntly rounded facial beak reddish, inner and lower orbits bordering face and jowls narrowly olive-buft pollinose, jowls and basioccipital region clothed with dark brown or blackish-brown hair; occiput dark olive-buff pollinose, appearing buffy-brown in certain areas and mummy-brown below vertex, clothed with fine, brownish hair, which has an ochraceoustawny or cinnamon-brown sheen, posterior orbits light buff pollinose, bare; first and second segments of palpi sepia-coloured, together shorter than distal seginent and clothed with dark brown or blackish-brown hair, distal segment russet-coloured, cylindrical, tapering somewhat towards tip and ending bluntly, with a few blackish hairs on inner side towards base; antennce thinly olive-buff or smoke-grey pollinose, first and second segments tawny, distal extremity of second segment fringed with bright ochraceous-tawny hairs, third (compound) segment russet-brown, terminal division paler (cinnamon- or pinkish-cinnamon-coloured). Thorax: dorsum of main portion (scutum) pale smoke-grey pollinose (ground-colour largely chestnut-brown or russet, groundcolour of humeral calli pinkish-buff), with two straight and complete, converging, longitudinal black stripes of uniform width, which in front are in contact with inner ends of humeral calli, and posteriorly meet together in prescutellar groove; in middle line a brownish, dusky stripe (visible at least when insect is regarded at an angle of $45^{\circ}$ from behind), commencing on front margin as an elongate black spot, extends backwards and becomes indistinct shortly after passing level of transverse suture; scutellum, except lateral extremities, which are whitish-grey pollinose and clothed with pale hair, blackish-brown, clothed above with short blackish hair, and below with brownish hair: lorsum of scutum clothed in front with short yellowish hair, and posteriorly with short blackish or black hair, on each side above pleuræ and in front of transverse suture an area of longer, dark brown or brownish hair, posteriorly ochraceous-tawny at base; 
pleuræ and upper border of pectus black, clothed with black or blackish hair, central area of pectus light greyish-olive pollinose (ground-colour chestnut-brown), clothed with fine, cinnamon-buffcoloured hair. Abdomen; first four tergites, at least in case of type, honey-yellow or isabella-coloured, here and there irregularly mottled with dark green or greyish-olive, their lateral extremities black, fifth tergite dark olive, rather less than posterior half of preceding tergite similarly coloured in centre, second and third tergites each with a large, bluntly triangular, silvery-white spot in each posterior angle, not quite reaching hind margin in either case, first tergite with a pair of very small whitish spots in corresponding position but further from hind margin, ovipositor black or blackish-brown (distal extremity cinnamon-coloured);

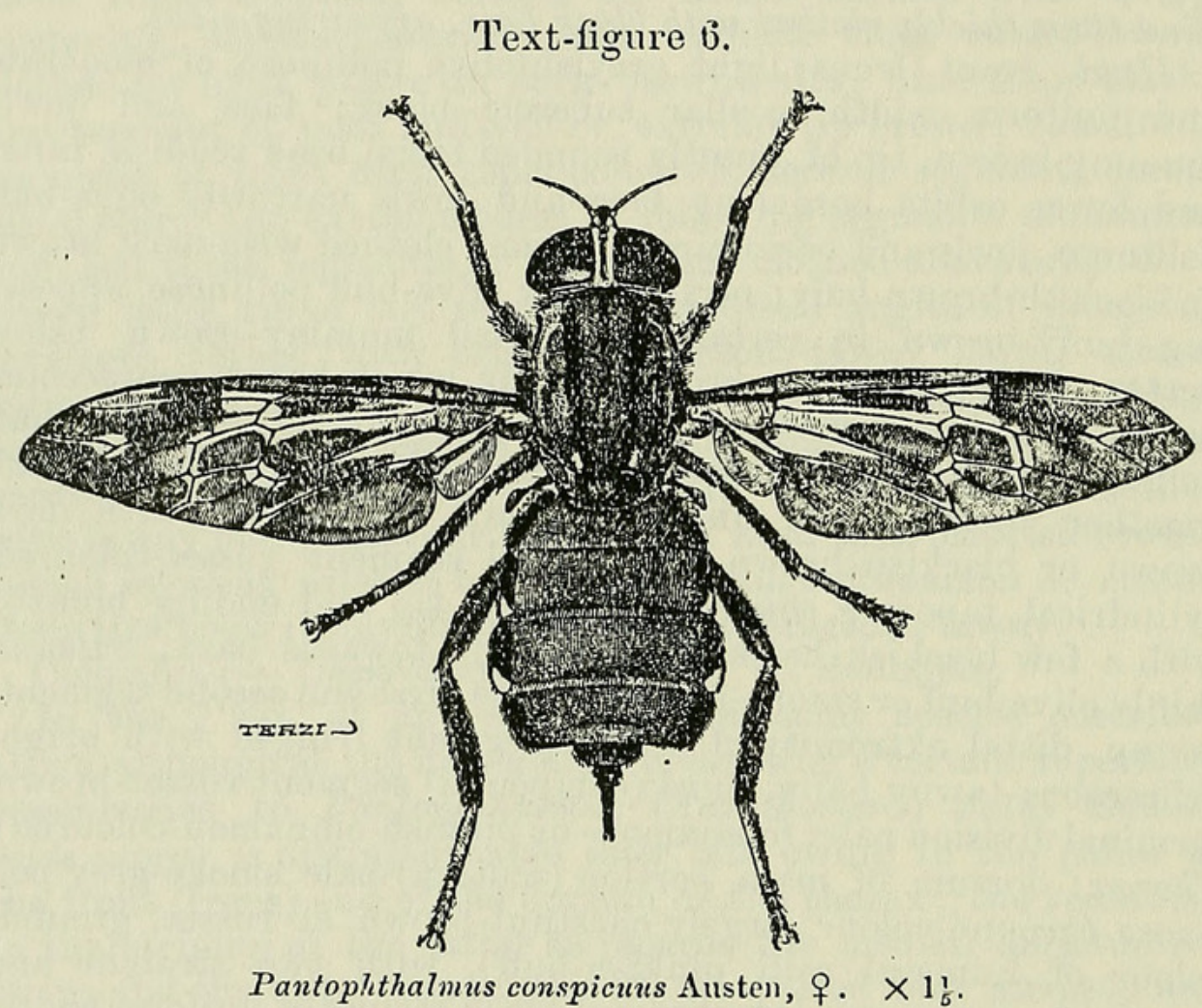

lateral border's of first four tergites, except silvery-white spots, clothed with fine, short, black hair, which, though longer on onter edges, does not form a conspicuous fringe; first four tergites, except lateral extremities, sparsely clotherl with short, or minute and inconspicuous, ochraceous-buff or ochraceous-orange hairs; first four sternites clove-brown (their lateral extremities blackishbrown), with a shimmering, smoke-grey, pollinose covering and sparsely clothed with short, ochraceous-orange hairs, ventral surface of projecting lateral extremities of first four tergites black, fifth sternite blackish-brown, sparsely clothed with similarly coloured hair, coloration of ventral surface of ovipositor. same as that of dorsal. Wings: infuscated (blackish-brown) area chiefly confined to distal third and posterior two-thirds, but first 
basal cell with an elongate dusky blotch occupying part of its distal two-thirds, but not extending either to tip or to hind border of the cell, an elongate brownish streak in second costa] cell above foregoing blotch, a large pale spot on fork of third longitudinal vein, and a more or less distinct pale streak along costa at tip of marginal call; infuscated area in discal cell not in contact with boundaries of cell at any point except on anterior basal transverse vein, across centre of which it is connected with large infuscated area in second basal cell, which again is continuous with infuscated axillary cell and alula, through infuscation occupying greater part of anal cell; veins inummybrown or cinnamon-brown. Halteres: stalks tawny-olive, knobs dusky dull green or dusky olive-green. Legs: coxæ and trochanters tawny or russet-coloured, clothed mainly with tawny or ochreous hairs, front coxæe on outer side blackish and clothed with similarly coloured hair; front and middle femora with a bluntly triangular projection at distal extremity, terminal spine on hind femora not unusually large ; front and middle femora chestnutbrown, with an ill-defined dark brown band before distal extremity, hind femora similarly coloured but darker, femora clothed mainly with dark brown or blackish hair, front and middle femora sparsely clothed at base on under side with short tawny hair, tips of all femora, at least above, and base of hind femora, clothed with glistening cinnamon-rufous hair, particularly noticeable at tips of hind femora on extensor surface, where it is short and closely appressed; front tibiæ russet, clothed largely with short, glistening tawny or cinnamon-rufous hairs, with longer and sparser dark brown hairs on extensor surface, middle tibire chestnut-brown (darker on anterior surface), extensor surface sparsely clothed with dark brown hair, flexor surface and tips, which are paler, clothed with short, glistening, appressed, cinnamon-rufous hair; hind tibire black (extreme tips paler and clothed with ochraceous-tawny hair); first three segments of front and middle tarsi, except tips, ochraceous-buff, last two segments and tips of preceding segments cinnainon-brown; front and middle tarsi entirely clotied with glistening, appressed, ochraceoustawny hairs, longer at distal extremity of upper surface of terminal segment, minute or short elsewhere; first segment of hind tarsi warm buff or cinnamon-buff (extreme tip faintly cinnamonbrown), clothed with short, glistening, appressed, cream-buff hair; last four segments of hind tarsi cinnamon-brown, clothed (as also extreme tip of first segment) with glistening, appressed, ochraceous-tawny hairs; claws tawny or russet-coloured, their tips black; pulvilli and empodia ochraceous-tawny.

British Honduras: Corozal, 26. ix. 1922, "came to light, at night" (Dr. F. L. Davis). The collector of the type, who has been kind onough to present the specimen to the National Collection, writes that, although resident in British Honduras for very many years, he cannot remember having met with this species previously. 
Apart from the coloration of the abdomen, as exhibited in the case of the typical specimen at least, Pantophthalmus conspicuus in the $q$ sex exhibits a certain superficial resemblance both to $P$. chuni Enderl. and P. conspicabilis Austen. From both of these species it is, however, distinguishable inter alia owing to the wings being broadly pale (cream-buff or buff-yellow) at the base, and to the facial beak being bluntly rounded at the tip instead of acuminate. From $P$. chuni, apart from any other characters, it is further distinguished by its stout, furry hind tibiæ, and pale front (frons).

The type of $P$. conspicuus was originally preserved and sent to the Museum in spirit, and there is reason to believe that, owing either to this, or to natural post-nortem changes, the coloration of the disc of the abdomen (exclusive of the lateral borders) has suffered alteration, and that it was originally green. 'This at any rate seems a natural deduction from the fact that truces of green are visible here and there in the first four abdominal tergites, and that the halteres are still more or less green (vide description above). In any case, this is not the only instance in which a representative of this family is more or less green in life, since, according to the late Prof. Hermann (Deutsch. Ent. Z., Jahrg. 1916, Heft i. pp. 43, 45, April 1, 1916), the Brazilian Pantophthalmus alienus Herm., in the female sex at any rate, in which the ground-colour of the abdomen is dull velvety-black, has the hind margins of the first four tergites apple-green, while there are indications that in life the scutellum and halteres are of the same colour. It is of course well known that in those instances among Diptera-highly exceptional if the Chironomidie be excluded-in which the predominant colour in life is green, the green pigment after death is often or usually, largely or entirely, replaced by yellow. As cases in point, it will suftice to mention Oxycera trilineata Fabr., and other Stratiomyila, such as the South American Odontomyia pulchra Wied.; 'Tabaurs fasciatus Fabr., of West and Central Africa; and the European Didec alneti Fln.

What is almost certainly the male sex of $P$. conspicuus is represented by a solitary of ( $c f$. text-fig. 7$)$ from the R. Amazons, Brazil (H. IV. Bates), in the Hope Department, University Museum, Oxford (ex coll. W. W. Saunders). The dimensions of this specimen are as follows :-Length $29.6 \mathrm{~mm}$; width of head just over $8 \mathrm{~mm}$. ; greatest width of abdomen (across hind margin of second tergite) $9.4 \mathrm{~mm}$. ; length of wing $24.4 \mathrm{~mm}$. Viewed from above and slightly from in front, the dorsum of the thorax, except the hind border of the scutellum, is unstriped and uniformly silvery, forming a striking colour-contrast with the dorsum of the abdomen, which is ochraceous-tawny; the lateral extremities of the first four abdominal tergites are black and deflexed, while the posterior angles of the second and third tergites are each occupied by a large, bluntly triangular, silverywhite spot, lateral borders and spots being scarcely noticeablo 
from above. The other principal external characters are as follows:-Head: frontal and vertical triangles smoke-grey pollinose, ocellar tubercle dark brown ; face and jowls sepia-coloured, jowls clothed with hair of similar hue, inner orbits bordering face narrowly pinkish-buff pollinose ; facial beak represented by a low, elongate oval, tawny-brown area, which is scarcely noticeable; occiput shimmering golden-ochraceous-buff pollinose, with darker reflections, and clothed with fine yellowish hair; palpi similar in colour to those of $q$, but distal segment considerably (about one-third) shorter than second; antenna sepia-coloured, style paler, third (compound) segment cuneate, flattened from side to side, and deepest (in a dorso-ventral direction) at about onefourth of its length from the base. Thorax: rather less than

\section{Text-figure 7.}

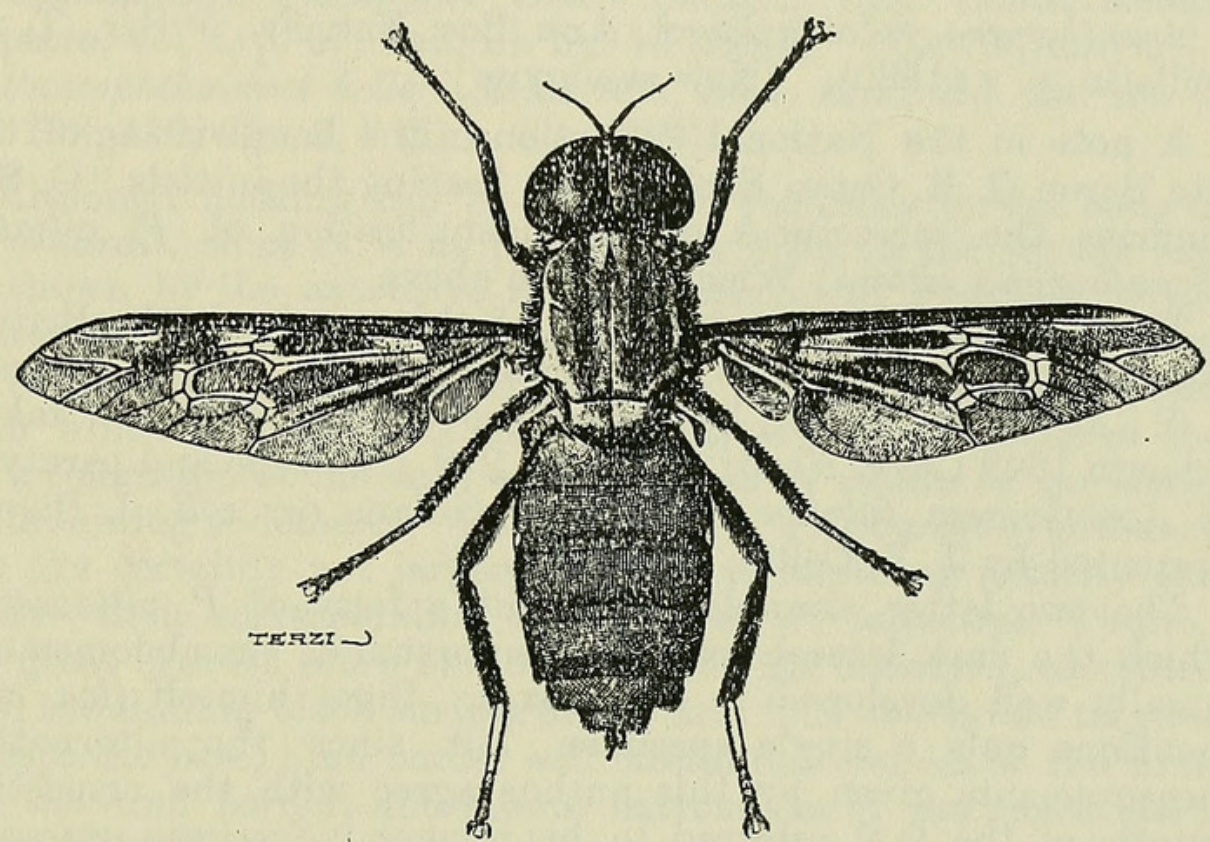

Presumptive $\delta$ of Pantophthalmus conspicuns Austen. $\times 1 \frac{1}{2}$. (From a specimen in the Hope Department, University Museum, Oxford).

posterior half of scutellum blackish-brown, clothed with brownish hair, dividing line between infuscated and silvery areas straight; dorsum of scutum, except lateral borders immediately above pleuræ, clothed with fine, short, reflexed, whitish hair, lateral borders clothed with longer hair, light ochraceous buff in front of, and yellowish behind transverse suture, under side of postalar calli blackish-brown; viewed at a slight angle from behind, dorsum of scutum shows unpigmented longitudinal stripes, corresponding to the paired black stripes and commencement of a median stripe exhibited by the $q$; pleuræe and lateral borders of pectus dark clove-brown or blackish-brown, clothed with similarly coloured hair, remainder of pectus light ochraceousbuff, clothed with fine, silky hair of similar colour. Abdomen: 
venter ochraceous-buff, pinkish-buff pollinose, sparsely clothed with tine, glistening ochreous hairs, lateral extremities of sternites brownish; dorsum, except lateral borders of first four segments, clothed with ochreous or ochraceous-buff hairs, for most part minute and inconspicuous except on first and sixth segments, lateral borders of first four tergites, except silvery-white spots, clothed with black or blackish hair. Wings (cp. text-figs. 6 \& 7) with markings corresponding extremely closely to those exhibited by $q$, but tips paler. Halteres cinnamon-buff. Legs agreeing in all essential respects with those of $q$; coloration of hind coxæ and their hairy covering as in case of adjacent area of pectus.

\section{Pantophthalmus vittatus Wied.}

Acanthomera vittata Wiedemann, Auss. zweifl. Ins. i. p. 109 (1828).

Acanthomera fulvida Bigot, Ann. Soc. Ent. Fr., 5e Sér., T. x., Bulletin, p. v (1880). [New synonym.]

A note in the National Collection in the handwriting of the late Baron C. R. Osten Sacken, and bearing the initials "O. S.," confirms the correctness of the identification of $P$. vittatus (Acanthomera vittata) Wied. as given above.

The following are the specimens of this species in the British Museum : a $\delta$, from the R. Amazons, Brazil (H. W. Bates); a $q$, also from Brazil, but exact provenance unknown, taken prior to 1849 (Mrs. Noel); and two $q$ o (the type and paratype of Acanthomerc fulvida Big.), from Guiana (ex coll. J. Bigot: presented by J. E. Collin, F.E.S.).

The two latter examples represent a form of $P$. viltatus in which the dark lateral spots on the dorsum of the abdomen are equally well developed in both sexes. Bigot himself (loc. cit.) mentions only a single specimen, but, since the alternative measurements given by this author agree with the respective lengths of the $q q$ referred to, his remark "Specimen unicum" is probably a lapsus calami.

There are six specimens of $P$. vittatus - all $q$ 은 in the Hope Department of the University Museum, Oxforà. Of these, three are simply labelled "Miers coll.", and bear no further indication of provenance; of the remainder, one has a label with the words "S. S. Saunders, Bahia, Bz."; another is labelled "E Mus. Saunders, $1867 "$; and a label attached to the sixth example shows that this specimen was taken in Brazil, and purchased from Higgins in 1871. Considerable variation in size is noticeable in the Oxford series; while the dimensions of the largest o (total length, including ovipositor and short facial beak, $32.25 \mathrm{~mm}$.; wing-expanse $57 \mathrm{~mm}$.) are approximately the same as those of Mrs. Noel's specimen in the National Collection, the corresponding measurements of the smallest example in the possession of the Hope Department are $24 \cdot 6 \mathrm{~mm}$. and $40 \mathrm{~mm}$. respectively-practically the same as those of the smaller of the 
two $q$ o from the Bigot collection, presented to the British Museum by Mr. Collin.

The $\sigma$ and $q$ in the British Museum, collected respectively by H. W. Bates and Mrs. Noel, are each pseudo-parasitized by nymphs of the usual species of Gamasid mite. In the case of the $\delta$, there is only a single Acarid, which is on the upper surface of the abdomen; the pseudo-parasites on the $q$ are present on both sides of the abdomen, and, although only in small numbers, are more plentiful above than below. One of the specimens in the Oxford collection is similarly infested.

\section{Pantophthalmus bellardii Bell.}

Acanthomera bellardii Bellardi, Saggio di Ditterol. Messicana, Appendice, p. 16, Tav. iii. fig. 11 (1862).

Acanthomera championi Osten Sacken, Biol. Centr.-Amer., Diptera, vol. i. p. 67, Tab. iii. fig. 16 (1886). [New synonym.]

Pantophthalmus helleri Enderlein, Zool. Anz., Bd. xli. no. 3, pp. 108, 110, tigs. 8, 9 (Dec. 20, 1912).

Although nothing can be said with reference to the male of $P$. bellardii, since it is at present unknown, in the female sex, as shown by the extensive series of specimens available to the writer for comparison, the species is normally one of the finest of its family, and is conspicuous, even among the huge Diptera with which this paper is concerned, as much on account of the dark coloration of the body and wings, as by reason of the shape of its shining abdomen. While females of $P$. bellardii of ordinary size are certainly not larger-perhaps if anything actually less bulky - than corresponding examples of $P$. tabaninus Thunb., the great breadth often exhibited by the flat abdomen, combined with the shining black surface of the first four abdominal tergites (except the base, hind border and lateral extremities of the tirst, and the hind borders and lateral extremities of the remainder), serves to make the present species noticeable among its congeners, among which, in actual size of the largest examples, females of $P$. tabaninus are its only rivals. It is therefore not a little curious, as well as unfortunate, that the holotype of $P$. bellardii -formerly in the Bigot collection, and generously presented to the British Museum (Natural History) by Mr. J. E. Collin, F.E.S. - is one of the smallest Pantophthalmids yet seen. The dimensions of a large female of $P$. bellardii in the National Collection are as follows:- Total length (ovipositor and short, blunt, facial beak included) $53.5 \mathrm{~mm}$; greatest breadth (measured across the third abdominal segment) $20 \cdot \overline{\mathrm{s}} \mathrm{mm}$; wing-expanse $86 \mathrm{~mm}$. (nearly $3 \frac{1}{2}$ inches). The corresponding measurements in the case of the type are respectively $24,9 \cdot 5$, and $43 \mathrm{~mm}$. Moreover, apart from its diminutive proportions, the type of $P$. bellardii is anything but typical, since it is faded, rubbed, and somewhat shrunken, having in all probability originally been preserved in spirit before being pinned. Nevertheless, the 
specific identity of Bellardi's type with even the largest member of the series of specimens under discussion is beyond question, and the examination of a small female of $P$. bellardii, which has been in the National Collection for upwards of fifty-five years, entirely supports this conclusion. In the latter specimen, as in the type, the shining transverse bands on the dorsum of the abdomen are russet-brown instead of black, and a similar color"ation is exhibited by one or more of the larger females of $P$. bellardii in the British Museum.

The particulars with reference to the fifteen specimens of this species (including the type and paratypes of Acanthomera championi O. Sack.) in the National Collection are as follows :One $q$ (holotype of the species), Mexico (-Sallé), ex coll. Bigot, presented by J. E. Collin, F.E.S. ; one 우 (type of Acanthomera championi O. Sack.), Chontales, Nicaragua (E. M. Janson); one q, Orizaba, Mexico (- Sallé); one + , Bugaba, Panama (G. C'. Champion); one \&, R. Dagua, Colombia (W.F. H. Rosenberg) ; one o, provenance unknown (ex coll. W. W. Saunders). The remaining nine specimens, presented to the British Museum (Natural History) by Mr. J. E. Collin, F.E.S., previously formed part of the collection of the late J. M. F. Bigot, where they were placed above the label " $A$. heydeni, Wied." * Of these examples, one is from Mexico, two are from Nicaragua, and the remainder (if the general label can be trusted) from Brazil.

Of the two females of $P$. bellardii belonging to the Hope Department, University Museum, Oxford, one is from Chontales, Nicaragua, 1870 (E. M. Janson), the other from Peru ("E Mus. Saunders, $1867 ")$.

From what has been stated above, it will have been seen that $P$. bellardii, at any rate in the female sex, is, like other species of Pantophthalmidæ, subject to great variation in size.

Infestation by Gamasid nymphs of the usual species is exhibited by at least two of the specimens in the National Collection; in the cases referred to, the pseudo-parasites in small numbers are elustered together beneath the hind margins of one or more of the distal abdominal tergites, commencing with the fourth. An Acarid pseudo-parasite of a different kind, determined by Mr. A. S. Hirst as an adult female of a species of Macrocheles, was found on the front (frons) of one of the Brazilian females from the Bigot collection.

According to Enderlein (Zool. Anz., Bd. xliv. no. 13, p. 585, July 28, 1914), P. helleri Enderl. is a synonym of P. (Acanthomera) championi $\mathrm{O}$. Sack. It would be impossible to arrive at such a conclusion from a perusal of Enderlein's original description of $P$. helleri (vide supra), in which the front (frons) in the female is explicitly stated to be narrowed posteriorly, and to be less than twice as long as broad.

\footnotetext{
* Acanthomera heydenii Wied., though treated as a valid species by Enderlein (Zool. Anz., Bd. xli. p. 102 (1912)), is in reality synonymous with Pantophthalmus tabanimus 'Thunb. (cf. p. 562).
} 
Pantophthalmus splendidus, sp. n. (Text-fig. 8.)

9.- Length (one specimen), including ovipositor and facial beak, $37.0 \mathrm{~mm}$.; width of head $8.4 \mathrm{~mm}$.; width of front at vertex $1.25 \mathrm{~mm}$.; greatest width of abdomen (across base of third tergite) $12.6 \mathrm{~mm}$; length of wing $28 \mathrm{~mm}$; wing-expanse $64 \cdot 65 \mathrm{~mm}$.

In o sex, at least as represented by type, handsome, blackishbrown, black and orange-rufous species, with small, inconspicuous and only moderately sharply pointed facial beak; dorsum of thorax bearing a pair of admedian, sharply defined and conspicuous, pale olive-buff pollinose, longitudinal stripes, apparent colour of which $i s$, in certain aspects, somewhat altered by hairy covering; bluntedged abdomen, in which anterior portion of both second and third tergites is shining, and dorsum of which is black at base, then largely orange-rufous, with a black border on each side, in which are a small white spot, and two short, transverse, silvery-white streaks; dusky wings, with sharply defined, cimnamon-buff markings, as shown in text-fig. 8; hind femora and tibice not so thickly clothed with hair as to appear furry, hind femora fairly stout, somewhat, though not very noticeably, incrassate towards tips, and with small subfemoral and terminal spines.

Head: front (frons), jowls and basioccipital region black or blackish-brown, face mummy-brown, inner orbits bordering face and at least upper portion of front more or less buffy-brown or sepia-coloured; front of moderate width, somewhat broader at anterior extremity than at vertex ; ocelli, at least in type, orangecinnamon; facial beak shining black, its base enveloped above with a narrow, matt, mummy-brown covering; jowls and basioccipital region clothed with fine, blackish-brown or dark mummy-brown hair; occiput smoke-grey pollinose, posterior orbits narrowly pale smoke-grey; palpi black or blackish-brown, distal segment somewhat swollen, pointed at tip, distinctly shorter than remaining portion of palpi, which is clother with blackish hair, distal segment clothed with similar hair at base, and bearing two or three hairs of same kind at tip ; antenna slender (i.e. depth of third (compound) segment not greatly increased at base), blackish-brown or black, paler towards distal extremity, terminal division of third segment greyish cinnamon-coloured at tip, first and second segments somewhat sparsely clothed with black hairs. Thorax: dorsum, so far as can be seen, with no trace of small or minute, shining, rounded, wart-like tubercles, with which as a rule in Pantophthalmidae this region is characteristically and plentifully besprinkled; scutellum, sides of main portion of dorsum (scutum) behind humeral calli, and central area of dorsum in front of prescutellar groove and behind ends of olive-buff pollinose stripes chestnut-brown, this hue being darker on sides of scutum and brighter in case of scutellum ; admedian, olive-buff pollinose stripes separated in middle line by a narrow, tapering, chocolatebrown stripe, and bordered on each side by a much broader, 
blackish or blackish-brown longitudinal stripe, which, commencing on front border and occupying entire space between humeral callus and corresponding admedian stripe, is continued backwards to prescutellar groove, becoming constantly narrower as it passes backwards, and in particular diminishing markedly in width after passing beyond end of olive-buff stripe, which itself disappears shortly after crossing transverse suture; behind latter, bordering each blackish or blackish-brown stripe on outer side, is a fairly broad, curved, shining stripe; humeral calli light ochraceous-buff in front, blackish-brown behind, outer extremity in each case shining, pointed, and reddish-brown; olive-buff pollinose stripes clothed with fine, ochraceous-tawny hair, remainder of dorstim of

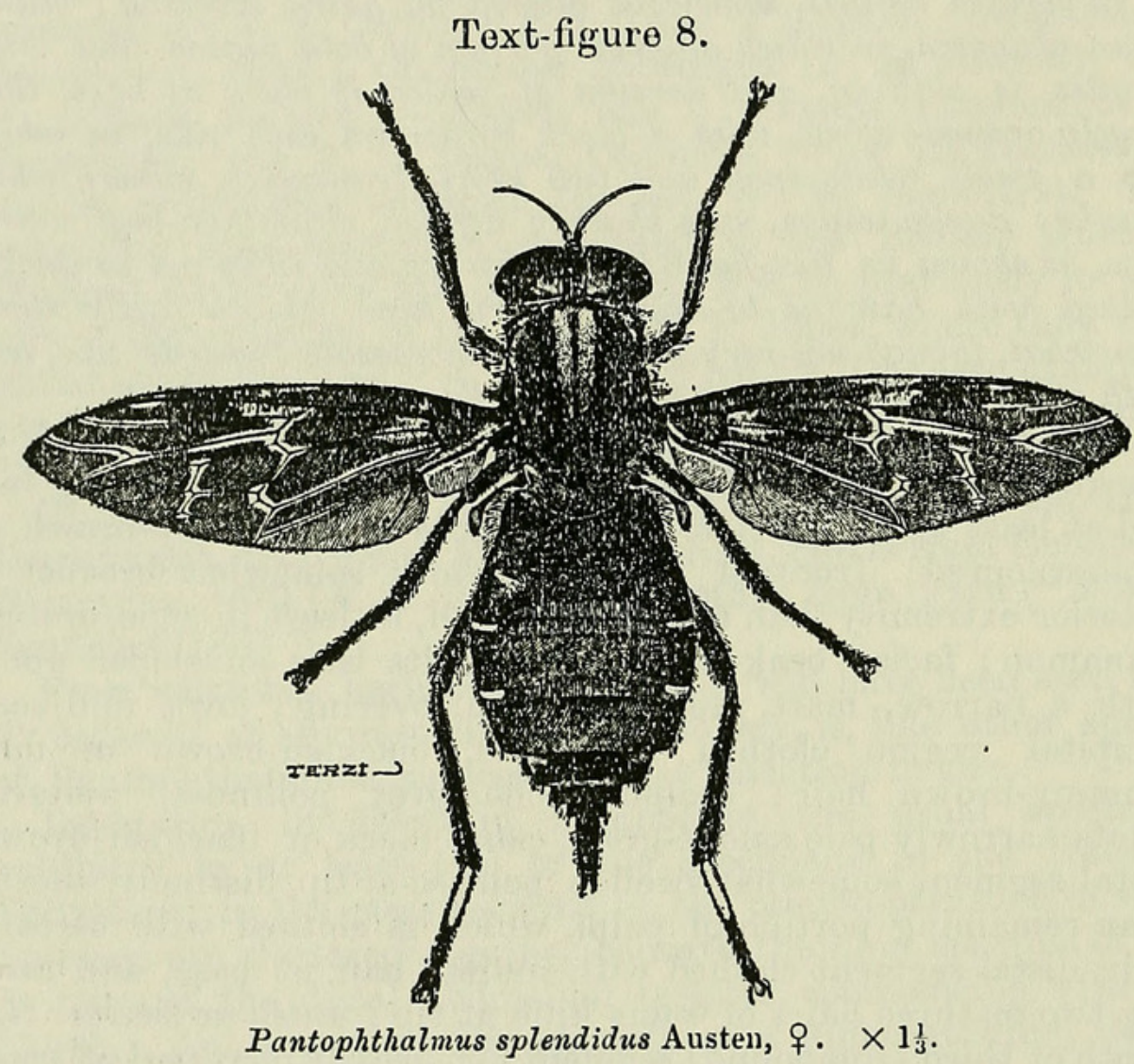

scutum covered with fine russet-brown or russet-coloured hair, lateral borders of scutum in front of transverse suture clothed with dark brown hair, scutellum and oblong median area immediately in front of it clothed with bright russet-coloured liair; pleuræ and pectus mummy-brown, clothed with similarly coloured hair, rounded knob below base of wing on each side shining blackish-brown. Ablomen: first tergite black, clothed with fine black or blackish hair, and having on each lateral edge, a short distance in front of posterior angle, a small white spot; second and two following tergites orange-rufous (shining anterior border of second tergite mainly reddish-brown, at least in case of type), lateral borders black, shading off somewhat into brown on 
inner margin, a short, transverse, silvery-white streak just in front of each posterior angle of second and third tergites; apart from silvery-white streaks just mentioned, on both second and third tergites non-shining area is confined to posterior half of segment, is of less depth than shining area in front of it, and has its extremities, which are far from reaching lateral margins, tapered and rounded off; fifth tergite black, moderately shining and narrowly margined (incompletely so in front) with orangerufous; remaining tergites blackish-brown or dark brown (terminal lobes or valves ochraceous-buff, spar'sely clothed with ochraceous-tawny hairs); orange-rufous area of dorsum, as also fifth tergite, thinly clothed with glistening, decumbent, ochraceoustawny hair, shining anterior border of second tergite clothed with similar hair, second and following tergites otherwise for most part thinly clothed with black hair; venter black (second and two or three following sternites shining), thinly clothed with black hairs. Wings (apart fiom cinnamon-buff markings) mummybrown over rather less than proximal three-fourths of costal border, then lighter or darker sepia-coloured, typical specimen at any rate with a distinctly paler area in centre of certain cells, such as discal and second posterior; cinnamon-buff markings more sharply defined and more restricted than in case of several other species of Pantophthalmus already described, chief markings being at base of basal cells (whence extensions are emitted, to costa on humeral transverse vein, and along fifth longitudinal vein), between costa and proximal extremity of discal cell (including anterior transverse vein and an extension thence for soms distance along third longitudinal vein), and streaks embracing respectively distal extremity of second, and anterior branch of third longitudinal veins, and distal boundaries of second basal and discal cells; costa clove:brown at base, otherwise mainly cinnamon-brown, veins elsewhere mummy-brown in darker, ochraceous-tawny in lighter areas. Halteres : (in dried condition, at any rate) stalks mummy-brown, knobs buff-yellow. Legs, except first segment of hind tarsi, uniformly black and clothed with black hair; fisst segment of hind tarsi light orange-rellow, clothed with short, ochraceous-orange hairs, tip of segment blackish-brown or black, clothed with similarly coloured hairs, extreme base of segment also blackish-brown; claws black; pulvilli and empodia ochraceous-buff.

Panama.: Chiriqui Volcano, between 5000 and $9000 \mathrm{ft}, 1915$ (H. J. Watson).

Owing to its distinctive coloration and markings, Pantophthalmus splendidus - in the of sex at any rate-cannot be confused with any of its congeners already known.

The specimen from which the above description has been drawn up bears, on the fifth and following abdominal segments, a small number of nymphs of the species of Gamasid mite (genus Trachytes) that has been mentionerl so often in the course of this paper as occurring on various species of Pantophthalmidæ. In addition to 
these pseudo-parasites, a few other nymphal mites, apparently conspecific with the foregoing, were found on the left side of the thorax, among the hair on the anterior border of the mesopleura.

\section{Pantophthalmus variegatus, sp. n. (Text-fig. 9.)}

. - Length (four specimens), including ovipositor and facial beak, 29.5 to $36.25 \mathrm{~mm}$; ; width of head 7.5 to $9.2 \mathrm{~mm}$.; width of front at vertex 1.4 to $1.5 \mathrm{~mm}$.; greatest width of abdomen (across hind border of second tergite) 9.8 to $13.0 \mathrm{~mm}$.; length of wing 25.0 to $28.5 \mathrm{~mm}$.

Strongly marked species, with, in 9 sex at any rate, dorsum of thorax vinaceous-buff, conspicuously striped and spolted with black or blackish-brown, and with dorsum of abdomen ochraceousorange or orange-rufous, with sharply defined black lateral borders, in each of which are four transversely elongate, silvery-white spots, the fourth pair of spots less conspicuous than the others and sometimes indistinct; facial beak prominent but not sharp pointed; wings strongly infuscated, mummy-brown at base, then sepiacoloured or fuscous, with ochraceous-buff or cream-buff marlcings as shown in text-fig. 9; hind femora incrassate towards tips, with very small terminul spine, subfemoral spine likewise small, difficult to distinguish among the hair.

Head: front (frons) warm buft, of moderate and unifor'm width; in middle line, just above bases of antennæ, a narrow, short, somewhat sagittate, brownish streak; ocellar tubercle black, bluntly ovate, sharply defined and conspicuous; face dark sealbrown (facial orbits narrowly olive-buff), below facial beak with an ochraceous-orange transverse band, extremities of which turn upwards on each side of base of beak, a similar but paler (light ochraceous-buff) band, about half the depth of the former, immediately. above bases of palpi; jowls and basioccipital region. mummy-brown or cinnamon-brown, clothed with similarly coloured hair; facial beak of moderate length, blunt (not sharppointed) at tip, which is shining black or blackish-brown, proximal three-fourths of beak enveloped, except below, with a matt, dark seal-brown, smooth (not transversely rugose) covering; occiput light buff (immediately adjacent to posterior orbits ochraceous-buff), clothed with glistening, ochraceous-buff hairs, which become brownish towards tips; first and second segments of palpi sepia-coloured or dark brown, clothed with reddish-brown or dark brown hair, and together longer than or at least as long as distal segment, latter blackish-brown or black (sepia-coloured at base), moderately swollen beyond proximal fourth, and sparsely clothed, at least on outer side and at base, with short, redlish-brown hair's; antennce warm buff, second segment with a circlet of russet coloured hairs at distal extremity, third (compound) segment slender, showing but little increase of depth at base. Thorax: dorsum of main portion (scutum) 
vinaceous-buff pollinose, with, as shown in text-fig. 9, on anterior two-thirds a pair of fairly broad, black or blackish-brown longitudinal stripes, and on each side, behind transverse suture, a pair of similarly coloured spots, the larger of which occupies postalar callus, while the other, much smaller spot is situate above base of wing, just behind outer extremity of transverse suture; a short distance in rear of latter, each longitudinal stripe becomes partially obliterated or is tapered off obliquely from in front outwards, and is then continued to prescutellar groove by a narrower and paler extension, each extension ending on anterior wall of groove in a somewhat ill-defined, darker, spot-like termination, which is in contact with its fellow ; scutellum black or blackish-brown, its outer extremities silver-grey pollinose on a pale ochraceous-

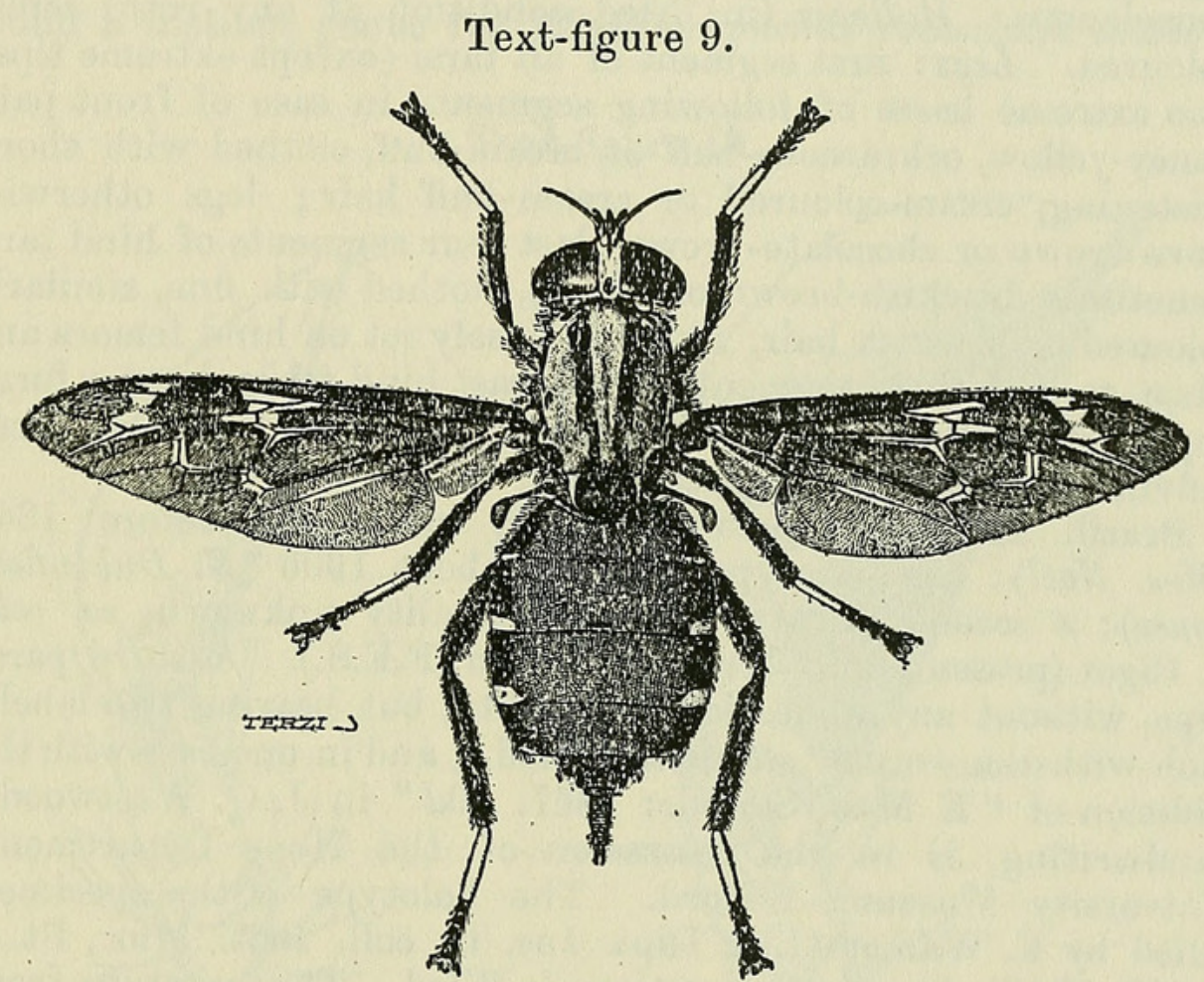

Pantophthalmus variegatus Austen,.$+ \times 1 \frac{1}{3}$.

buff ground; dorsum of scutum clothed with ochraceous-buft hair, stripes, spots, and scutellum clothed with brownish or dark brown hair; humeral calli warm buff or cream-buff, outer extremities and a spot on upper surface at base dark brown; pleure and pectus mummy-brown, clothed with similarly coloured hair. Abdomen: first four tergites, at least in typical series, ochraceous-orange or orange-rufous, their lateral extremities, which are somewhat deflexed, black and sharply defined, with a transversely elongate, silvery-white spot in posterior angle of each tergite, spots on fourth tergite smaller than the others and sometimes indistinct; remaining tergites, including ovipositor, mummy-brown, a larger or smaller area in centre of base of fifth 
tergite ochraceous-orange or orange-rufous; sixth and seventh tergites, fifth tergite except area just mentioned, and lateral borders of preceding tergites, except silvery-white spots, clothed with dark brown, blackish or black hair; first tergite, except, lateral extremities, thinly clothed with fine, decumbent, glistening ochraceous-buff hairs, remainder of ochraceous-orange or orangerufous area of dorsum very sparsely clothed with short or minute hairs of similar colour; venter mummy-brown, thinly clothed with fine, dark brown hair. Wings: markings very similar to those exhibited by Pantophthalmus batesi Austen (cf. figs. 9 and 2); costa, from a short distance beyond base, mainly cinnamoncoloured; veins elsewhere partly mummy-brown, partly sepiacoloured, except in pale areas where they are cinnamon-buft; teguliform swelling at base of costa ochraceous-buff, large and conspicuous. Halteres (in dried condition at any rate) sepiacoloured. Legs : first segment of all tarsi (except extreme tips), also extreme bases of following segments in case of front pair, honey-yellow, ochraceous-buff or cream-buff, clothed with short, glistening, cream-coloured or cream-buff hair; legs otherwise clove-brown or chocolate-brown (last four segments of hind tarsi sometimes blackish-brown or black), clothed with fine, similarly coloured or blackish hair, which is closely set on hind femora and tibiæ, so that these segments, or at least hind tibiæ, have a furry appearance; claws black; sometimes russet-coloured at base; pulvilli and empodia ochraceous-buff.

Brazil. Holotype, precise locality unknown, before 1849 (Mrs. Noel); one paratype, Parana, about 1906 (E. Dukinfield Jones); a second paratype, precise locality unknown, ex coll. J. Bigot (presented by Mr. J. E. Collin, F.E.S.). A third paratype, without any indication of locality, but bearing two labels, each with the words "seticornis, Wied.", and in one case with the addition of "E Mus. Saund.: 1867. 10d" in J. O. Westwood's handwriting, is in the possession of the Hope Department, University Museum, Oxford. The holotype is the specimen called by F. Walker (List Dipt. Ins. in coll. Brit. Mus., Pt. i. p. 210, 1848) Acanthomera seticornis $\mathrm{W}$ ied. The paratype from the Bigot collection was placed by its original owner above the label "A. frauenfeldi, Schiner." It may be of interest to note that, in the wings of the paratype from Parana, the second posterior cell is closed and petiolate, although in all other respects, apart from post-mortem shrinkage of the abdomen, the specimen is normal.

While the thoracic spots in the case of Pantophthalmus variegatus, $q$, are similar to those exhibited by both sexes of $P$. vittatus Wied., though the posterior lateral spot is much larger in the species characterized above, the distinctive thoracic stripes in $P$. variegatus will at once serve to separate it, not only from $P$. vitiatus, but also from any other Pantophthalmid in which at any rate the female sex is known.

It only remains to add that nymphs of the usual species 
of Gamasid mite, albeit in small numbers, are present on the abdominal tergites of at least two of the paratypes, as well as on those of the holotype of $P$. variegatus.

Genus Rhaphiorhynchus Wiedemann.

Rhaphiorhynchus Wiedemann, Diptera Exotica, Pars i. p. 59 (1821).

In spite of the lapse of more than a century since this genus was first described, the genotype, Rhaphiorhynchus planiventris Wied., is still the only species that can be assigned to it; as explained below ( $c f$. p. 597), it now seems more reasonable to. found a distinct genus for 1Rhaphiorhynchus rothsshildi Austen,

\section{Text-figure 10.}
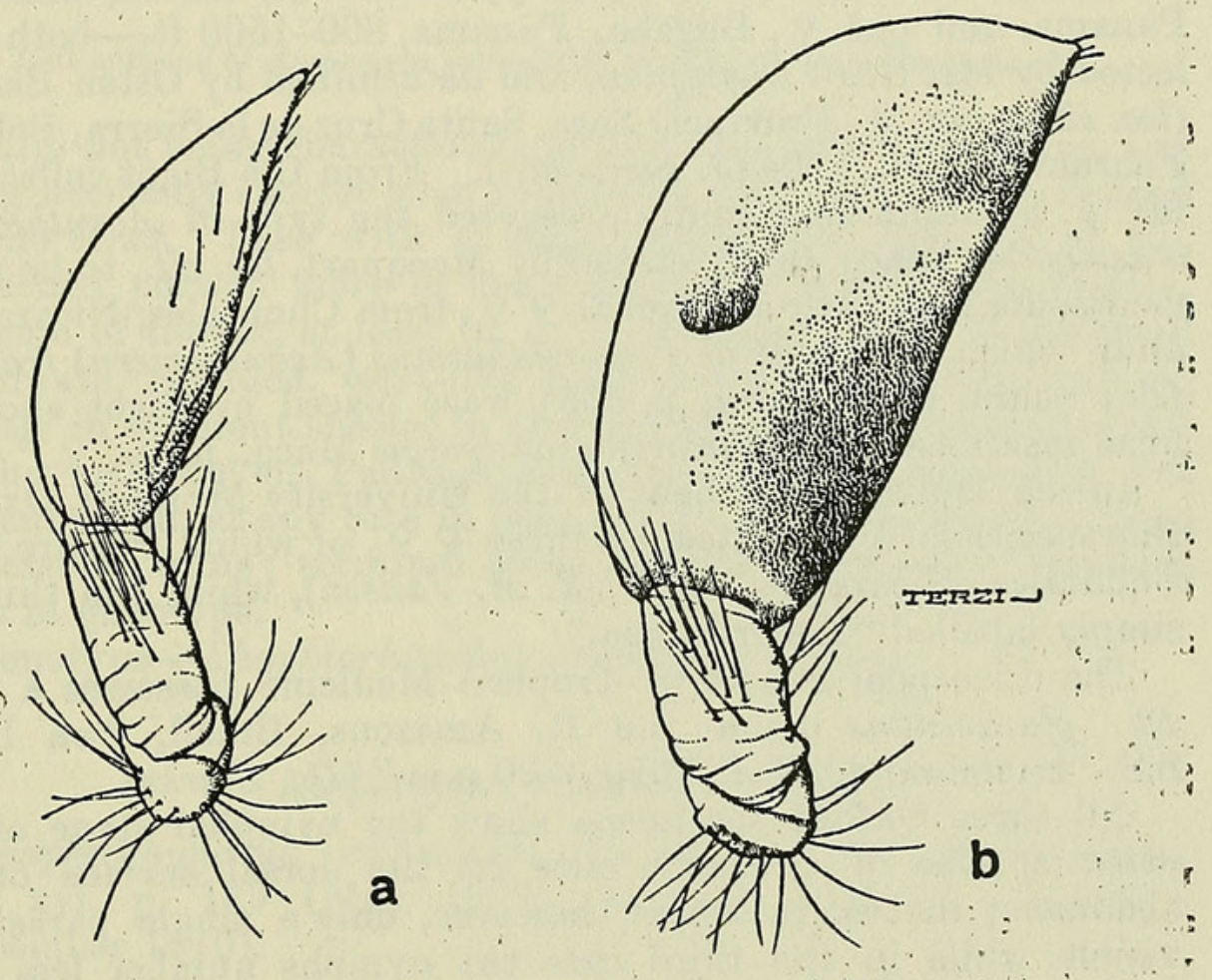

Left maxillary palpus of Rhaphiorhynchus planiventris Wied. : $a, \delta, b, q . ;$ Inner (ventral) aspect in each cuse.

which was described in 1909. At the same time, the distinctive shape of the terminal segment of the palpus in Rhaphiorhynchus planiventris, especially in the female, precludes any thought of including this species in the genus Pantophthalmus. As shown in fig. 10, the distal segment of the palpus in Rhaphiorhynchus, while distinctly swollen and fusiform in the male, is enormously: dilated in the opposite sex and, viewed from below, is decidedly reniform. A prominent and sharp-pointed facial beak, and a

Proc. Zool. Soc.-1923, No. XXXIX. 
well-developed subfemoral spine on the hind legs are present in both sexes.

\section{Rhaphiorhynchus planiventris Wied.}

Rhaphiorhynchus planiventris Wiedemann, Dipt. Exot. i. p. 60, Tab. ii. fig. 1 (1821).

Acanthomera crassipalpis Macquart, Mém. Soc. roy. des Sc., dè l'Ágric. et des Arts de Lille, Année 1846, p. 43, Tab. i. tig. 3 (1847).

Acanthomera bigoti Bellardi, Saggio di Ditterol. Messicana, Appendice, p. 16, 'Tav. iii. fig. 10 (1862).

The specific identity of Acanthomera crassipalpis Macq. and A. bigoti Bell. with Rh. planivertris Wied. was recognized long ngo by Baron C. R. Osten Sacken (Biol. Centr.-Amer., Diptera, vol. i. p. $66(1886))$.

The undermentioned specimens of $R h$. planiventris are in the British Museum (Natural History):-One $\sigma^{*}$, David, Chiriqui, Panama, and one $q$, Bugaba, Panama, 800-1500 ft.-both collected by Mr. G. C. Champion, and determined by Osten Sacken (loc. cit.); one $q$, Provincia Sara, Santa Cruz de la Sierra, Bolivia, February-A pril, 1904 (J. Steinbach). From the Bigot collection, Mr. J. E. Collin has kindly presented the type of Acanthomera crassipalpis Macq. (a $q$, stated by Macquart, loc. cit., to be from Guatemala), and two additional $q$, from Chontales, Nicaragua, all of which, with a $q$ of Pantophthalmus (Acanthomera) frauenfeldi Schin. (vide supra, p. 565), were placed by Bigot aboye a label inscribed "Acanthomera crassipalpis Macq., n. sp..$+ "$

In the Hope Department of the University Museum, Oxford, this species is represented by three $q q$, of which two are from Chontales, Nicaragua, 1870 ( $E . M$. Janson), while the third is simply labelled "America, aeq."

'The Liverpool School of 'T'ropical Medicine possesses a $q$ of Rh. planiventris from the $\mathrm{R}$. Amazons, Brazil, "on board S.S. 'Hildebrand,' 25.ii. 1920, 6.30 p.m." (Dr. Clarke).

All three Oxford specimens show the nymphal stage of the usual species of Gamasid mite on the dorsal surface of the abdomen; in two instances, however, only a single parasite is visible, while in the third case the nymphs number less than a dozen.

\section{Genus Atopomyia*, nov.}

Distinguished, at leàst in o sex, from both Pantophthalmus Thunb. and Rhaphiorhynchis Wied. by the narrow, elongate shape of the body, and the forin of the third (compound) segment of the antenna. The latter, instead of its broader (proximal) portion being more or less abruptly truncate (or tapering quickly to a point), and bearing terminally a fine, setiform arista (as in 
Pantophthalmus o), or being lanceolate (as in Rhaphiortignnchus planiventris Wied., ठ 8 , apud Macquart, Mém. Soc. Roy. des Sc., de l'Agric. et des Arts de Lille, Année 1838, 2 ième Partie, pl. 20. figs. $3,3 a, 1838$ ), is narrow and subulate, with its terminal annulus elongate, rod-like, abruptly attenuate and pointed at the tip, and bearing a few minute hairs towards the end, in addition to a longer recumbent hair above and below, just before the middle. Distinguished further, from both genera mentioned, by the palpi (at least in $\delta$ ) being densely clotherl with stiff hair, instend of the distal segment being practically bare; distinguished also from Rhaphiorhynchus by distal segment

Text-figure 11.

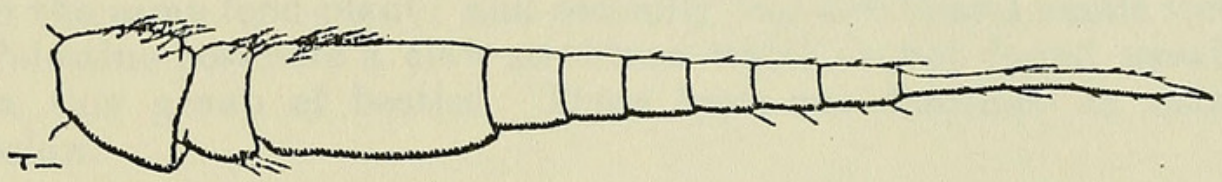

Left antenna of Atoponyia rothschildi Austen, $ठ \bar{\sigma}$, from the inner side.

of palpi not being characteristically swollen as in that genus, and being decidedly shorter than remaining portion of palpus, instead of vice versâ. Face with a large, thick beak, pointed at tip, thickened portion more or less distinctly wrinkled transversely. Dorsum of thorax, at least in $\delta$ of genotype, devoid of the small or minute, rounded, wart-like tubercles, which, though varying greatly in different species in size and number, are characteristic of the majority of Pantophthalmidæ, though apparently not present in all, at any rate in both sexes. Hind legs with a large subfemoral spine; terminal spine on hind femora very small, at least in genotype.

Genotype-Rhaphiorhynchus rothschildi Austen.

\section{Atopomyia rothschildi Austen.}

Rhaphiorhynchus rothschildi Austen, Novitates Zoologicæ, vol. xvi. p. 129 (May 1909), and vol. xvii. pl. xv. fig. I (December 1910).

Although at the time of describing this striking species the author considered that there were no real grounds for separating it from Khaphiorhynchus ( $c f$. Austen, t. cit. vol. xvi. p. 130), it seems advisable on further consideration to reverse this view, especially when regard is paid to the important palpal characters to which attention is drawn in the generic diagnosis above.

'The type of $A$. rollschildi-a of from Buenavista, Bolivia (J. Steinbach) -is in the Tring Museum, and the British Museum (Natural History) possesses a paratype of the same sex from Ecuador (Buckley). During the fourteen yenrs that have elapsed since the species was described, no further specimens of it have 
been added to the National Collection or seen by the author; but it may be noted that two $\delta^{\circ} \delta$ of $A$. rothschildi, from Peru and Chiriqui, Panama, respectively, were in the possession of the late Professor Hermann ( $c f$. Hermann, Deutsch. Ent. Z., Jahrg. 1916, Heft i. p. 47, 1916).

According to Lotd Rothschild (Nov. Zool. vol. xvii. p. 461, December 1910), Atopomyice rothschildi mimics the Hymenopteron Pepsis elevata Fabr., which is doubtless the explanation of the curious contrast in its general facies presented by this species, as compared with any other Pantophthalmid at present known. 


\section{$2 \mathrm{BHL}$ Biodiversity Heritage Library}

Aijsten, Major E E. 1923. "30. A Revision of the Family Pantophthalmidae [Diptera], with Descriptions of New Species and a new Genus." Proceedings of the Zoological Society of London 1923, 551-598.

https://doi.org/10.1111/j.1096-3642.1923.tb02198.x.

View This Item Online: $\underline{\text { https://www.biodiversitylibrary.org/item/97650 }}$

DOI: https://doi.org/10.1111/j.1096-3642.1923.tb02198.x

Permalink: https://www.biodiversitylibrary.org/partpdf/72007

\section{Holding Institution}

Smithsonian Libraries

\section{Sponsored by}

Biodiversity Heritage Library

\section{Copyright \& Reuse}

Copyright Status: Public domain. The BHL considers that this work is no longer under copyright protection.

This document was created from content at the Biodiversity Heritage Library, the world's largest open access digital library for biodiversity literature and archives. Visit BHL at https://www.biodiversitylibrary.org. 